\title{
Dual-strategy of hetero-engineering and cation doping to boost energy- saving hydrogen production via hydrazine-assisted seawater electrolysis
}

\author{
Qingping $\mathrm{Yu}^{1,2 \dagger}$, Jingqi Chi ${ }^{1,4 \dagger}$, Guishan Liu ${ }^{1,3}$, Xuanyi Wang ${ }^{1,2}$, Xiaobin $\mathrm{Liu}^{1,3^{*}}$, Zhenjiang $\mathrm{Li}^{1}$, \\ Ying Deng ${ }^{1,5}$, Xinping Wang ${ }^{1}$ and Lei Wang ${ }^{1,2,3^{*}}$
}

\begin{abstract}
When compared with pure water, hydrogen produced by seawater electrolysis has a better practical application potential. By replacing the oxygen evolution reaction (OER) and competitive chlorine evolution reaction (CIER) with the thermodynamically favorable anodic hydrazine oxidation reaction $(\mathrm{HzOR})$ in alkaline seawater, energy-saving hydrogen production can be achieved. In this study, $\mathrm{Fe} / \mathrm{Co}$ dual-doped $\mathrm{Ni}_{2} \mathrm{P}$ and MIL-FeCoNi heterostructures (FeCo$\left.\mathrm{Ni}_{2} \mathrm{P} @ M I L-F e C o N i\right)$ arrays with simultaneous cation doping and hetero-engineering provide excellent bifunctional electrocatalytic performance for $\mathrm{HzOR}$ and hydrogen evolution reaction (HER) in alkaline seawater electrolyte. Overall hydrazine splitting $(\mathrm{OHzS})$ in seawater is impressive, with a low cell voltage of only $400 \mathrm{mV}$ required to reach $1000 \mathrm{~mA} \mathrm{~cm}^{-2}$ and stable operation for $1000 \mathrm{~h}$ to maintain above $500 \mathrm{~mA} \mathrm{~cm}^{-2}$. As a proof-of-concept, the $\mathrm{OHzS}$ system can save $3.03 \mathrm{~kW} h$ when producing 1.0 normal cubic meter $\left(\mathrm{Nm}^{3}\right)$ of $\mathrm{H}_{2}$ when compared with the $\mathrm{N}_{2} \mathrm{H}_{4}$-free seawater system, resulting in energy-saving $\mathrm{H}_{2}$ production. Density functional theory calculations show that the combination of Co-doping and the fabrication of $\mathrm{FeCo}-\mathrm{Ni}_{2} \mathrm{P}$ and $\mathrm{MIL}-\mathrm{FeCoNi}$ heterointerfaces can result in a low water dissociation barrier, optimized hydrogen adsorption free energy toward HER, and favorable adsorbed dehydrogenation kinetics for $\mathrm{HzOR}$. This processing route paves the way for a practical approach to the efficient utilization of hydrogen, which is abundant in the ocean energy field, to achieve a carbon-neutral hydrogen economy.
\end{abstract}

Keywords: metal-organic framework, bifunctional electrocatalyst, seawater splitting, energy-saving hydrogen production

\section{INTRODUCTION}

In the context of the low-carbon and energy transition, pure water electrolysis is demonstrating a rapid development trend on a global scale [1-5]. Given the scarcity of pure water under natural conditions [6], hydrogen production via seawater electrolysis has a higher practical application value [7]. Nonetheless, the inevitable oxygen evolution reaction (OER) and competitive chlorine evolution reaction (ClER) on the anode limit the performance of seawater splitting. On the one hand, OER's intrinsically slow kinetics necessitate a high overpotential $(1.23 \mathrm{~V}$ vs. reversible hydrogen electrode (RHE)) to complete a complex four-electron process [8-10]. On the other hand, for seawater splitting in alkaline media, chloride anions react with $\mathrm{OH}^{-}$at the anode to form hypochlorite, triggering the anodic chlorine evolution reaction, thus resulting in electrode corrosion and environmental pollution, which reduces electrolysis efficiency and sustainability $[11,12]$. It should also be noted that the required voltage for the formation of hypochlorite in seawater [13] is only about $480 \mathrm{mV}$ higher than that required for anodic OER under alkaline conditions, offering limited space for hydrogen economy development and making ClER the bottleneck for realizing bifunctional catalysis [7]. As a result, alternative techniques for overcoming the thermodynamically sluggish anodic reaction in seawater splitting are highly desired.

It has recently been demonstrated that replacing anodic reactions with thermodynamically favorable small-molecule oxidation reactions, such as urea, tetrahydroisoquinoline, benzyl alcohol, and hydrazine, can significantly reduce the cell voltage for water splitting and achieve energy-saving $\mathrm{H}_{2}$ production [14]. Among these, the hydrazine oxidation reaction ( $\mathrm{HzOR}$, $\mathrm{N}_{2} \mathrm{H}_{4}+4 \mathrm{OH}^{-} \rightarrow \mathrm{N}_{2}+4 \mathrm{H}_{2} \mathrm{O}+4 \mathrm{e}^{-},-0.33 \mathrm{~V}$ vs. RHE) stands out for having a significantly lower theoretical potential than OER and the only byproduct of $\mathrm{N}_{2}$ being more safety [15] (see Fig. 1a). Furthermore, electrocatalytic $\mathrm{HzOR}$ provides a possible pathway for removing hydrazine from industrial sewage, which is expected to bring significant benefits in not only industrial sewage degradation but also energy-saving hydrogen production. Based on the foregoing, Li et al. [16] built three-dimensional (3D) hierarchical arrays (Ni NCNA) onto nickel foam for hydrazine oxidation-assisted hydrogen evolution, achieving a much lower voltage of only $0.124 \mathrm{~V}$ to afford $100 \mathrm{~mA} \mathrm{~cm}^{-2}$ in the assembled two-electrode system, which is $1.583 \mathrm{~V}$ lower than that of the corresponding overall water splitting (OWS) system. Despite these exciting breakthroughs in pure alkaline water,

\footnotetext{
${ }^{1}$ Key Laboratory of Eco-chemical Engineering, Key Laboratory of Optic-electric Sensing and Analytical Chemistry of Life Science, Taishan Scholar Advantage and Characteristic Discipline Team of Eco Chemical Process and Technology, Qingdao University of Science and Technology, Qingdao 266042, China

${ }^{2}$ College of Chemistry and Molecular Engineering, Qingdao University of Science and Technology, Qingdao 266042, China

${ }^{3}$ College of Environment and Safety Engineering, Qingdao University of Science and Technology, Qingdao 266042, China

${ }^{4}$ College of Chemical Engineering, Qingdao University of Science and Technology, Qingdao 266042, China

${ }^{5}$ Hainan Key Laboratory of Laser Technology and Photoelectric Functional Materials, Collage of Chemistry \& Chemical Engineering, Hainan Normal University, Haikou 571158, China

${ }^{\dagger}$ These authors contributed equally to this work

* Corresponding authors (emails: liuxb@qust.edu.cn (Liu X); inorchemwl@126.com (Wang L))
} 

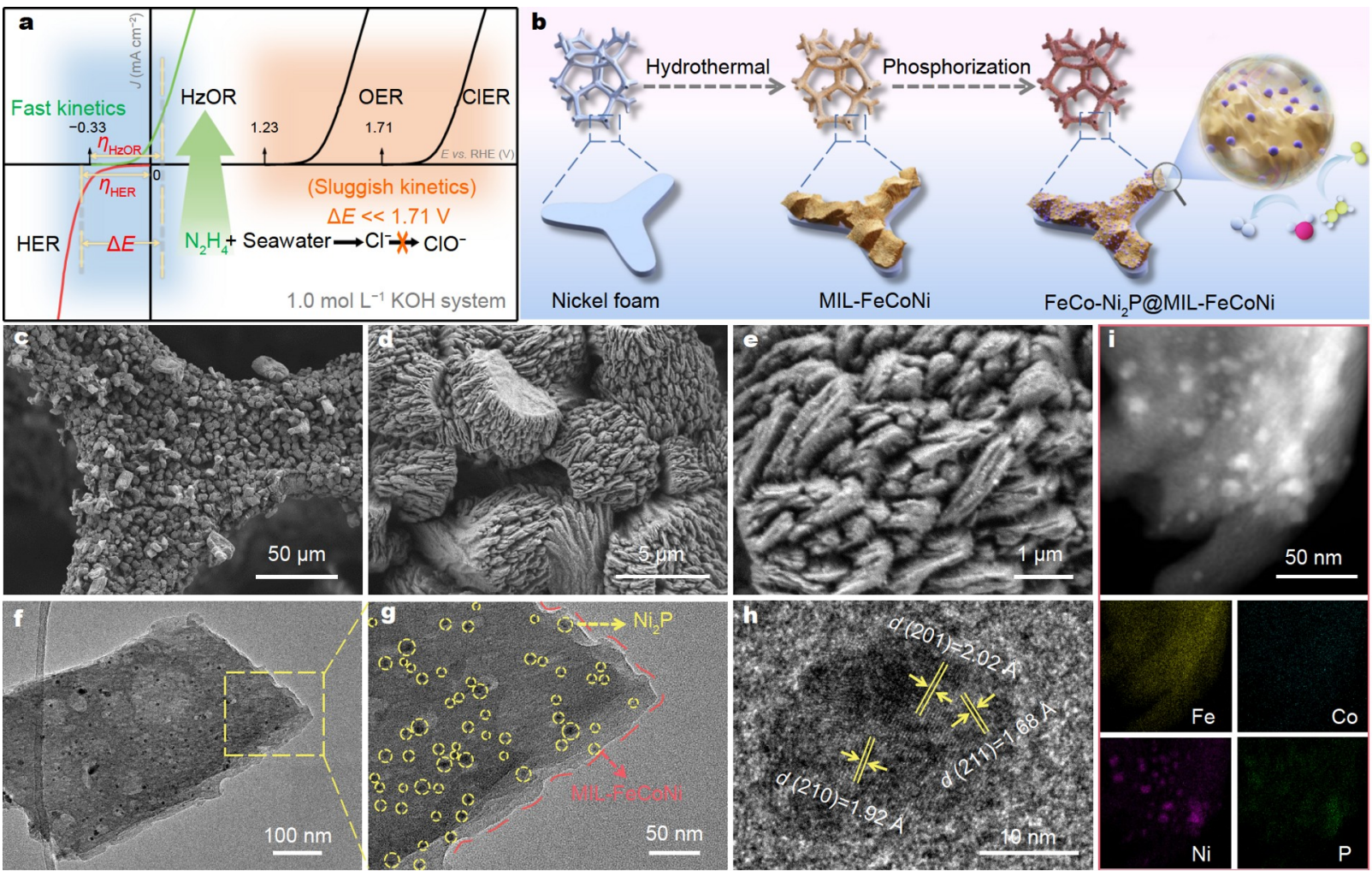

Figure 1 (a) Schematic illustration of the hydrazine-assisted seawater electrolysis for the energy-saving hydrogen production. (b) Schematic illustration of the formation process. (c-e) Field emission scanning electron microscopy (FESEM) images at different magnifications. (f, g) TEM images. (h) HRTEM analysis. (i) HAADF-STEM image and the corresponding elemental mapping results.

some unprecedented challenges in the alkaline seawater system remain to be solved. First, the current electrocatalysts in twoelectrode electrolyzers are far below the industrial hydrogen production standards, which require extremely high current densities (500-1000 $\mathrm{mA} \mathrm{cm}^{-2}$ ) [17]. Second, the electrocatalysts should perform well in terms of corrosion resistance and stability to overcome the unfavorable effect of high corrosivity and poisoning from non-innocuous ions in seawater on electrocatalytic performance $[11,18]$. Furthermore, it is highly desirable to integrate distinct active sites suitable for bifunctional catalytic processes into a single material to simplify processing installation and to have indepth understandings of the catalytic mechanisms for the integrated hydrogen evolution reaction (HER) and HzOR system to guide the design of advanced catalysts.

As is generally known, because the two components promote each other, hetero-engineering may be a powerful strategy for designing high-efficiency electrocatalysts that can promote electron transfer, adjust adsorption/desorption energy, and ultimately improve catalytic performance. Zhang's group [19] synthesized a NiCo/MoNi ${ }_{4}$ heterostructure catalyst with enhanced HzOR and HER bifunctionality as a result of combining the NiCo and $\mathrm{MoNi}_{4}$ phases into a unified system. The $\mathrm{Ni}_{3} \mathrm{~N}-\mathrm{Co}_{3} \mathrm{~N}$ porous nanosheet arrays reported by Qian et al. [20] demonstrated remarkable bifunctional activity with low overpotentials of -43 and $-88 \mathrm{mV}$ to reach $10 \mathrm{~mA} \mathrm{~cm}{ }^{-2}$ for HER and $\mathrm{HzOR}\left(0.1 \mathrm{~mol} \mathrm{~L}^{-1} \mathrm{~N}_{2} \mathrm{H}_{4}\right)$ in $1.0 \mathrm{~mol} \mathrm{~L}^{-1} \mathrm{KOH}$, respectively, owing to interfacial electron transfer between the $\mathrm{Ni}_{3} \mathrm{~N} / \mathrm{Co}_{3} \mathrm{~N}$ interface. Cation doping, on the other hand, has proven to be a promising alternative strategy for achieving outstanding catalytic activity for $\mathrm{HzOR}$ and HER, for example, the Fe-doped $\mathrm{CoS}_{2}$ nanosheet array reported by Ding and colleagues [21]. The above encouraging studies have inspired us to continue working on the development of an advanced electrocatalyst for integrating hetero-engineering and cation doping into one catalyst, with the goal of creating an excellent bifunctional catalyst for energy-saving hydrogen production in complex alkaline seawater, which is significant and almost unreported. We have successfully synthesized the $\mathrm{Fe} / \mathrm{Co}$ dual-doped $\mathrm{Ni}_{2} \mathrm{P}$ and MIL$\mathrm{FeCoNi}$ heterostructure arrays in-situ grown on nickel foam ( $\mathrm{FeCo}-\mathrm{Ni}_{2} \mathrm{P} @ \mathrm{MIL}-\mathrm{FeCoNi}$ ) via a hydrothermal process followed by controllable phosphorization strategy, taking into account the unique chemical and structural advantages of metal-organic frameworks (MOFs) [22-28] and metal phosphides [3,29-32]. The as-prepared $\mathrm{FeCo}-\mathrm{Ni}_{2} \mathrm{P} / \mathrm{MIL}-\mathrm{FeCoNi}$ arrays exhibit extraordinary bifunctional catalytic activity toward $\mathrm{HzOR}$ and HER in alkaline seawater medium, which only requires an ultrasmall potential of $42 \mathrm{mV}$ to achieve $1000 \mathrm{~mA} \mathrm{~cm}^{-2}$ for $\mathrm{HzOR}$ in $1.0 \mathrm{~mol} \mathrm{~L}^{-1} \mathrm{KOH}+0.5 \mathrm{~mol} \mathrm{~L}^{-1} \mathrm{~N}_{2} \mathrm{H}_{4}$ seawater, and $-310 \mathrm{mV}$ to achieve $1000 \mathrm{~mA} \mathrm{~cm}{ }^{-2}$ for HER in $1.0 \mathrm{~mol} \mathrm{~L}^{-1} \mathrm{KOH}$ seawater. Notably, the assembled FeCo- $\mathrm{Ni}_{2} \mathrm{P} @ \mathrm{MIL}-\mathrm{FeCoNi}$ electrodes in the two-electrode electrolyzer for overall hydrazine splitting $(\mathrm{OHzS})$ in seawater system require an ultralow voltage of $0.40 \mathrm{~V}$ to drive a high current density of $1000 \mathrm{~mA} \mathrm{~cm}^{-2}$ and long-term stability to keep above $500 \mathrm{~mA} \mathrm{~cm}{ }^{-2}$ for at least $1000 \mathrm{~h}$, implying a great potential for energy-saving $\mathrm{H}_{2}$ production compared with OWS in seawater system, and the density functional thoery (DFT) calculations show that the synergy of the abundant FeCo$\mathrm{Ni}_{2} \mathrm{P} / \mathrm{MIL}-\mathrm{FeCoNi}$ interface and Co substitution results in an optimized hydrogen adsorption free energy $\left(G_{\mathrm{H}}\right)$ toward HER 
and adsorbed $\mathrm{NH}_{2} \mathrm{NH}_{2}$ dehydrogenation kinetics for $\mathrm{HzOR}$. To the best of our knowledge, this is the first time we have applied MOFs and metal phosphides to the alkaline $\mathrm{OHzS}$ process and interpreted the underlying mechanisms of $\mathrm{HER} / \mathrm{HzOR}$ catalytic activity, pointing out the direction of designing advanced catalysts for cost-effective and sustainable hydrogen production.

\section{RESULTS AND DISCUSSION}

\section{Synthesis and characterization of FeCo-Ni ${ }_{2} \mathrm{P} @ M I L-F e C o N i$ nanosheet arrays}

The FeCo- $\mathrm{Ni}_{2} \mathrm{P} @ \mathrm{MIL}-\mathrm{FeCoNi}$ nanosheet arrays assembled on nickel foam were synthesized using a facile two-step hydrothermal process followed by phosphorization, as shown schematically in Fig. 1b, in which commercial $\mathrm{Ni}$ foam with a smooth surface (Fig. S1) was used as both the Ni source and the conductive substrate. First, the 3D flower-like precursor nanosheet arrays (denoted as MIL-FeCoNi) are hydrothermally grown in-situ on nickel foam. The panoramic views of MILFeCoNi at various magnifications (Fig. S2a, c) reveal wellassembled nanosheet clusters uniformly and densely grown on $\mathrm{Ni}$ foam. Notably, such 3D flower-like nanosheet clusters could expose a large surface area, increasing the density of electrochemically active sites and allowing for more reaction space for subsequent reactions. The final FeCo- $\mathrm{Ni}_{2} \mathrm{P} @ \mathrm{MIL}-\mathrm{FeCoNi}$ heterostructure is then produced by phosphorizing MIL-FeCoNi in an inert atmosphere. The as-prepared FeCo- $\mathrm{Ni}_{2} \mathrm{P} @ \mathrm{MIL}-\mathrm{FeCoNi}$ heterostructure retains the dense and uniform nanosheet array morphology, as shown in Fig. 1c, d, indicating the stable structure of MIL-FeCoNi as a precursor. Surprisingly, the phosphorization process results in the formation of many ultrafine nanoparticles on the surface of MIL-FeCoNi arrays (Fig. 1e). Furthermore, Fig. S3 depicts the change in color of the $\mathrm{Ni}$ foam during the entire synthesis process, demonstrating the homogeneous growth of these active species. High-resolution transmission electron microscopy (HRTEM) images were used to examine the morphological and structural information of the as-prepared FeCo- $\mathrm{Ni}_{2} \mathrm{P} @ \mathrm{MIL}-\mathrm{FeCoNi}$ arrays. The typical TEM image in Fig. 1f shows that the FeCo- $\mathrm{Ni}_{2} \mathrm{P} @ \mathrm{MIL}-\mathrm{FeCoNi}$ arrays are made up of well-dispersed nanosheets, and each nanosheet is decorated with numerous isolated dark nanoparticles with an average size of $\sim 5 \mathrm{~nm}$ that form during phase transformation in the phosphorization process. The HRTEM analyses show that FeCo- $\mathrm{Ni}_{2} \mathrm{P} @ \mathrm{MIL}-\mathrm{FeCoNi}$ has rich, heterogeneous interfaces composed of MIL-FeCoNi nanosheets and phosphide nanoparticles, which are marked with yellow lines in Fig. 1g. HRTEM determines the interplanar spacings in Fig. $1 \mathrm{~h}$ to be 2.02, 1.92, and $1.68 \AA$, corresponding to the (201), (210), and (211) planes of $\mathrm{Ni}_{2} \mathrm{P}$, respectively. The formation of a $\mathrm{FeCo}-\mathrm{Ni}_{2} \mathrm{P} / \mathrm{MIL}-$ $\mathrm{FeCoNi}$ heterostructure, which can produce an interfacial bonding effect and is beneficial for improving electrocatalytic performance, is directly demonstrated by the clear dark grain boundary. To further reflect the compositions of nanosheets and nanoparticles, the high-angle annular dark-field scanning TEM (HAADF-STEM) and the corresponding mapping analysis (Fig. 1i), as well as the energy dispersive X-ray spectroscopy (EDS) spectrum (Fig. S4), show that Fe and Co elements are uniformly distributed throughout the nanosheets, whereas $\mathrm{Ni}$ and $\mathrm{P}$ elements are primarily overlapped at the position of the nanoparticles, which differ from MIL-FeCoNi (Fig. S5).

$\mathrm{X}$-ray diffraction (XRD) patterns of the samples are shown in
Fig. 2a to further reveal the compositions of various samples. The diffraction peak at $8.9^{\circ}$ for $\mathrm{FeCo}-\mathrm{Ni}_{2} \mathrm{P} @ \mathrm{MIL}-\mathrm{FeCoNi}$ is indexed to the (200) plane of the MIL-53(Fe) structure. The peaks at $40.8^{\circ}, 47.3^{\circ}, 54.2^{\circ}$, and $91.0^{\circ}$ are indexed to the (111), (210), (300), and (312) planes of $\mathrm{Ni}_{2} \mathrm{P}$ (JCPDS No. 03-0953), respectively, demonstrating the coexistence of MIL-53(Fe) and $\mathrm{Ni}_{2} \mathrm{P}$ in the FeCo- $\mathrm{Ni}_{2} \mathrm{P} @ \mathrm{MIL}-\mathrm{FeCoNi}$ hybrid. These findings show that the structure of MIL-53(Fe) is preserved after phosphorization. The diffraction patterns of $\mathrm{Fe}_{-} \mathrm{Ni}_{2} \mathrm{P} @ \mathrm{MIL}-\mathrm{FeNi}$ and FeCo- $\mathrm{Ni}_{2} \mathrm{P} @ \mathrm{MIL}-\mathrm{FeCoNi}$ are nearly identical, indicating that Co dopants have no effect on the phase of the hybrid. Notably, when compared with FeCo-Ni $\mathrm{N}_{2} \mathrm{P}$ MIL-FeCoNi, the $\mathrm{FeCo}-\mathrm{Ni}_{2} \mathrm{P}$ is composed entirely of the $\mathrm{Ni}_{2} \mathrm{P}$ phase, with no appearance of MIL-53(Fe) after phosphorization. Furthermore, for all samples, there are three prominent and sharp diffraction peaks at $44.5^{\circ}$, $51.8^{\circ}$, and $76.3^{\circ}$, which correspond to the (111), (200), and (220) crystal faces of Ni foam (JCPDS No. 04-0850), respectively, derived from the conductive $\mathrm{Ni}$ substrate. The X-ray photoelectron spectroscopy (XPS) analysis on $\mathrm{FeCo}_{\mathrm{Ni}} \mathrm{P} @ \mathrm{MIL}-$ FeCoNi and control samples was performed to gain a better understanding of the valence states, electronic interactions, and Co-doping effect. The survey spectrum confirms the presence of $\mathrm{Fe}, \mathrm{Co}, \mathrm{Ni}, \mathrm{P}, \mathrm{C}$, and $\mathrm{O}$ elements in $\mathrm{FeCo}-\mathrm{Ni}_{2} \mathrm{P} @ \mathrm{MIL}-\mathrm{FeCoNi}$ as well as the element compositions in control samples (Fig. S6). The Co 2 p spectra of all samples (Fig. 2b) show two spin-orbit peaks at around 782.2 and $798.1 \mathrm{eV}$, corresponding to the $\mathrm{Co}^{2+}$ $2 \mathrm{p}_{3 / 2}$ and $\mathrm{Co}^{2+} 2 \mathrm{p}_{1 / 2}$ orbitals, respectively [33]. Furthermore, the XPS spectra for $\mathrm{FeCo}-\mathrm{Ni}_{2} \mathrm{P} @ \mathrm{MIL}-\mathrm{FeCoNi}$ and $\mathrm{Fe}-\mathrm{Ni}_{2} \mathrm{P} @ \mathrm{MIL}-$ FeNi show emerging peaks at 778.5 and $793.4 \mathrm{eV}$ corresponding to the $\mathrm{Co}^{\delta+}$ [34]. Fig. $2 \mathrm{c}$ shows the XPS spectra of Fe $2 \mathrm{p}$ in FeCo$\mathrm{Ni}_{2} \mathrm{P} @ M I L-F e C o N i, F e C o-N i_{2} \mathrm{P}$, and MIL-FeCoNi. Fe ${ }^{2+} 2 \mathrm{p}_{3 / 2}$ and $\mathrm{Fe}^{2+} 2 \mathrm{p}_{1 / 2}$ are assigned to the peaks at 711.0 and $724.3 \mathrm{eV}$, respectively. The $\mathrm{Fe}^{3+}$ has higher binding energy, which is located at 715.0 and $728.5 \mathrm{eV}$. Furthermore, the $\mathrm{Fe}^{\delta+}[13]$ is assigned a peak at $704.9 \mathrm{eV}$ for $\mathrm{FeCo}-\mathrm{Ni}_{2} \mathrm{P} @ \mathrm{MIL}-\mathrm{FeCoNi}$ and $\mathrm{FeCo}-\mathrm{Ni}_{2} \mathrm{P}$. The high-resolution XPS spectrum of $\mathrm{Ni} 2 \mathrm{p}$ in FeCo-Ni $\mathrm{N}_{2} \mathrm{P} @ \mathrm{MIL}-\mathrm{FeCoNi}$ (Fig. 2d) could be divided into a pair of $\mathrm{Ni}^{2+} 2 \mathrm{p}_{1 / 2}$ and $\mathrm{Ni}^{2+} 2 \mathrm{p}_{3 / 2}$ peaks at 874.8 and $856.7 \mathrm{eV}$, respectively, as well as two satellite peaks at 879.7 and $861.4 \mathrm{eV}$. Furthermore, the binding energy at 870.5 and $853.2 \mathrm{eV}$, corresponding to the $\mathrm{Ni}^{\delta+}$ peaks, can be seen in the XPS spectra for both $\mathrm{FeCo}-\mathrm{Ni}_{2} \mathrm{P} @ \mathrm{MIL}-\mathrm{FeCoNi}$ and $\mathrm{Fe}-\mathrm{Ni}_{2} \mathrm{P} @ \mathrm{MIL}-\mathrm{FeNi}$, indicating the successful synthesis of $\mathrm{Ni}_{2} \mathrm{P}$ species [25]. The XPS spectra of $\mathrm{Fe} 2 \mathrm{p}$ and $\mathrm{Ni} 2 \mathrm{p}$ for $\mathrm{Fe}-\mathrm{Ni}_{2} \mathrm{P} @ \mathrm{MIL}-\mathrm{FeNi}$ and FeCo$\mathrm{Ni}_{2} \mathrm{P} @ M I L-F e C o N i$ are shown in Fig. 2e, $\mathrm{f}$ to help interpret the effect of cation Co-doping on the electronic structure. It is worth noting that the binding energies of the Fe species in the FeCo$\mathrm{Ni}_{2} \mathrm{P} @$ MIL-FeCoNi were positively shifted by about $0.3 \mathrm{eV}$ when compared with those of $\mathrm{Fe}-\mathrm{Ni}_{2} \mathrm{P} @ \mathrm{MIL}-\mathrm{FeNi}$. The binding energy of $\mathrm{Ni}$ species shifted toward lower values by about $0.3 \mathrm{eV}$ when compared with those of $\mathrm{Fe}_{-} \mathrm{Ni}_{2} \mathrm{P} @ \mathrm{MIL}-\mathrm{FeNi}$. The electron interaction between $\mathrm{Fe}, \mathrm{Ni}$, and $\mathrm{Co}$ caused by the addition of $\mathrm{Co}$ into $\mathrm{Fe}-\mathrm{Ni}_{2} \mathrm{P} @ \mathrm{MIL}-\mathrm{FeNi}$ causes a shift in binding energies, which is critical in modulating electronic properties and thus promoting catalytic performance [25]. Furthermore, the intensity of the $\mathrm{P} 2 \mathrm{p}$ peaks in the $\mathrm{FeCo}-\mathrm{Ni}_{2} \mathrm{P} @ \mathrm{MIL}-\mathrm{FeCoNi}$ spectrum is higher than that in the Fe- $\mathrm{Ni}_{2} \mathrm{P} @ \mathrm{MIL}-\mathrm{FeNi}$ spectrum (Fig. S7), indicating that the combination of $\mathrm{P}$ with $\mathrm{Ni}$ is enhanced, leading to improved conductivity of this phosphide [35]. The XPS results presented above show that hetero-engineering and cation doping can cause electronic interaction between different 

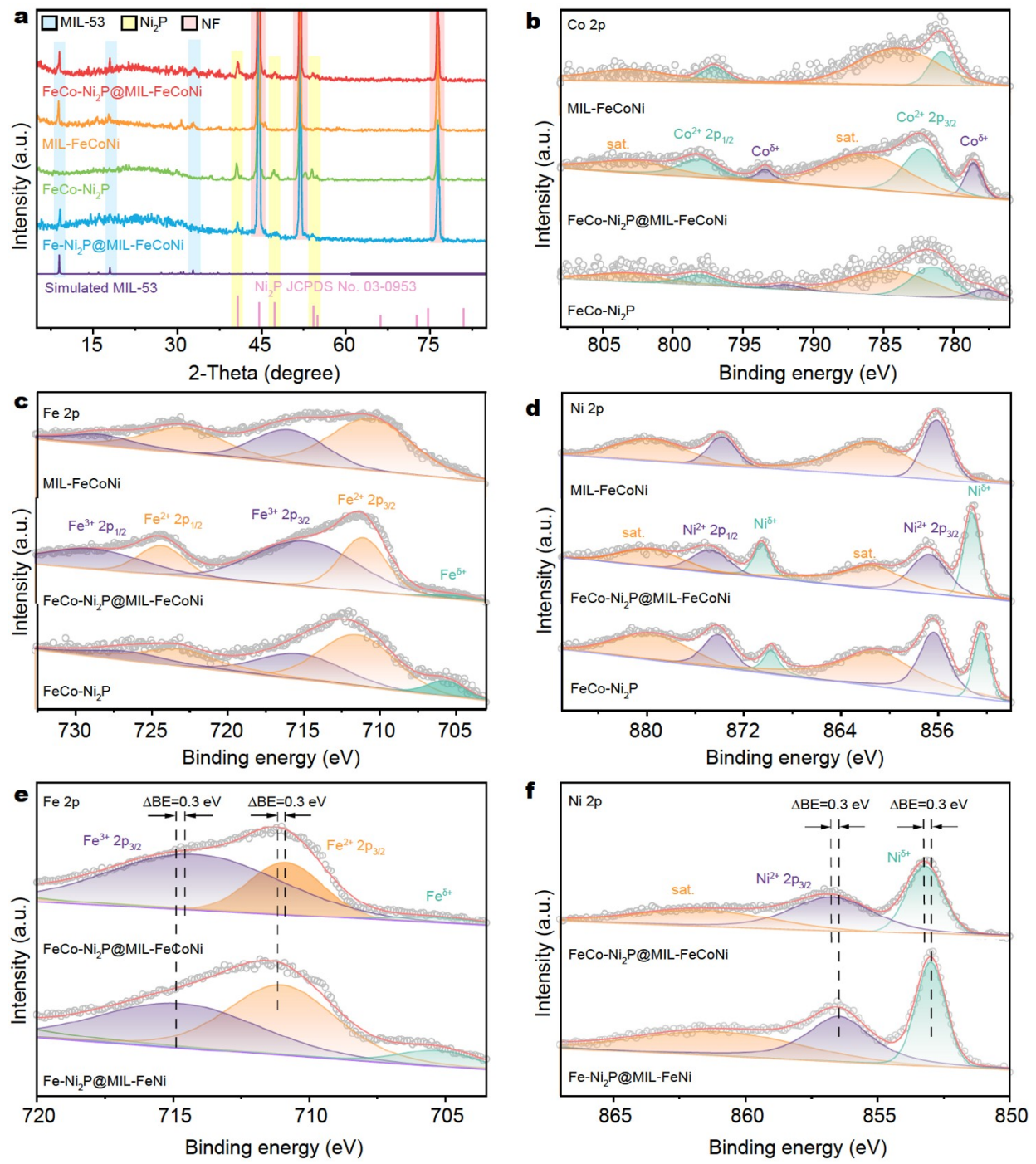

Figure 2 XRD patterns and high-resolution XPS spectra of FeCo- $\mathrm{Ni}_{2} \mathrm{P} @ \mathrm{MIL}-\mathrm{FeCoNi}, \mathrm{MIL}-\mathrm{FeCoNi}, \mathrm{Fe}-\mathrm{Ni}_{2} \mathrm{P}$ and Fe-Ni $2 \mathrm{P} @ \mathrm{MIL}-\mathrm{FeNi}$. (a) XRD pattern. High-resolution XPS spectra of (b) Co 2p, (c) Fe 2p, (d) Ni 2p, (e) Fe 2p $\mathrm{p}_{3 / 2}$ and (f) Ni $2 \mathrm{p}_{3 / 2}$.

components.

\section{Investigation of electrocatalytic HzOR and HER activities}

To investigate the role of hetero-engineering and cation Codoping in electrocatalytic performance, we evaluated the activities of $\mathrm{FeCo}-\mathrm{Ni}_{2} \mathrm{P} @ \mathrm{MIL}-\mathrm{FeCoNi}$ catalyst in $1.0 \mathrm{~mol} \mathrm{~L}^{-1} \mathrm{KOH}$ with $\mathrm{FeCo}-\mathrm{Ni}_{2} \mathrm{P}$, MIL-FeCoNi, and $\mathrm{Fe}-\mathrm{Ni}_{2} \mathrm{P} @ \mathrm{MIL}-\mathrm{FeNi}$ as control samples. According to the OER and HER polarization curves shown in Figs S8 and S9, the FeCo- $\mathrm{Ni}_{2} \mathrm{P} @ \mathrm{MIL}-\mathrm{FeCoNi}$ electrode exhibits exceptional OER and HER activity, higher than those of $\mathrm{FeCo}-\mathrm{Ni}_{2} \mathrm{P}, \mathrm{MIL}-\mathrm{FeCoNi}, \mathrm{Fe}-\mathrm{Ni}_{2} \mathrm{P} @ \mathrm{MIL}-\mathrm{FeNi}$, commercial $\mathrm{Ni}$ foam, even outperforming the benchmark $\mathrm{RuO}_{2}$ or $\mathrm{Pt} / \mathrm{C}$, and many recently reported non-noble metal-based catalysts (Tables S1 and S2), verifying the excellent catalytic activity of $\mathrm{FeCo}_{\mathrm{Ni}} \mathrm{P} @ \mathrm{MIL}-\mathrm{FeCoNi}$ in $1.0 \mathrm{~mol} \mathrm{~L}^{-1} \mathrm{KOH}$. Inspired by the excellent activity of $\mathrm{FeCo}-\mathrm{Ni}_{2} \mathrm{P} @ \mathrm{MIL}-\mathrm{FeCoNi}$ in $1.0 \mathrm{~mol} \mathrm{~L}^{-1} \mathrm{KOH}$, we also evaluated the performance of the FeCo- $\mathrm{Ni}_{2} \mathrm{P} @ \mathrm{MIL}-\mathrm{FeCoNi}$ catalyst in alkaline simulated seawater $\left(1.0 \mathrm{~mol} \mathrm{~L}{ }^{-1} \mathrm{KOH}+0.5 \mathrm{~mol} \mathrm{~L}-1 \mathrm{NaCl}\right)$, alkaline natural seawater $\left(1.0 \mathrm{~mol} \mathrm{~L}^{-1} \mathrm{KOH}\right.$ seawater), and alkaline hydrazine natural seawater ( $1.0 \mathrm{~mol} \mathrm{~L}^{-1} \mathrm{KOH}+0.5 \mathrm{~mol} \mathrm{~L}^{-1} \mathrm{~N}_{2} \mathrm{H}_{4}$ seawater) elec- trolytes. As shown in Fig. S10, our FeCo- $\mathrm{Ni}_{2} \mathrm{P} @ \mathrm{MIL}-\mathrm{FeCoNi}$ electrode performs excellently in the simulated seawater electrolyte. It is worth noting that the $\mathrm{FeCo}-\mathrm{Ni}_{2} \mathrm{P} @ M I L-F e C o N i$ electrode exhibits no obvious attenuation even in the alkaline natural seawater electrolyte with high corrosiveness, and the performance of the FeCo- $\mathrm{Ni}_{2} \mathrm{P} @ \mathrm{MIL}-\mathrm{FeCoNi}$ electrode in either of these electrolytes is exceptional, coming close to that in $1.0 \mathrm{~mol} \mathrm{~L}^{-1} \mathrm{KOH}$. The excellent performance of the FeCo- $\mathrm{Ni}_{2} \mathrm{P} @ \mathrm{MIL}-\mathrm{FeCoNi}$ electrode in the above electrolyte demonstrates that bacteria/microbes, insoluble precipitates, and small particulates in natural seawater cause little damage to electrode surface active sites. Notably, when the linear sweep voltammetry (LSV) curves of $\mathrm{FeCo}-\mathrm{Ni}_{2} \mathrm{P} @ \mathrm{MIL}-\mathrm{FeCoNi}$ in $0.5 \mathrm{~mol} \mathrm{~L}^{-1} \mathrm{~N}_{2} \mathrm{H}_{4}$ alkaline seawater are compared with other alkaline electrolytes, the ultrahigh electrocatalytic activity for the $\mathrm{HzOR}$ is clearly visible, demonstrating the great potential of FeCo- $\mathrm{Ni}_{2} \mathrm{P} @ \mathrm{MIL}-\mathrm{FeCoNi}$ for energy-saving hydrogen production via the $\mathrm{N}_{2} \mathrm{H}_{4}$-assisted strategy (Fig. S10a). To investigate the effect of phosphorization further, the phosphorus amount used in the synthesis of FeCo-Ni ${ }_{2} \mathrm{P} @ M I L-F e C o N i$ was examined, and it is shown that the sample obtained with the addition of $1.5 \mathrm{~g}$ of 
$\mathrm{NaH}_{2} \mathrm{PO}_{2}$ has the best $\mathrm{HzOR}$ and $\mathrm{HER}$ catalytic activity (Figs S11 and S12).

To further investigate the excellent $\mathrm{HzOR}$ activity of FeCo$\mathrm{Ni}_{2} \mathrm{P} @ M I L-F e C o N i$, Fig. 3a shows the LSV curves of FeCo- $\mathrm{Ni}_{2} \mathrm{P}$ @MIL-FeCoNi, Fe-Ni 2 P@MIL-FeCoNi, MIL-FeCoNi, bare $\mathrm{Ni}$ foam, and $\mathrm{RuO}_{2}$ in $1.0 \mathrm{~mol} \mathrm{~L}-1 \mathrm{KOH}+0.5 \mathrm{~mol} \mathrm{~L}^{-1} \mathrm{~N}_{2} \mathrm{H}_{4}$ seawater electrolyte, which indicates the excellent electrocatalytic activity of FeCo- $\mathrm{Ni}_{2} \mathrm{P} @ M I L-F e C o N i$ compared with other samples. Specifically, the FeCo-Ni 2 P@MIL-FeCoNi requires ultralow working potentials of -52 and $42 \mathrm{mV}$ to achieve high current densities of 100 and $1000 \mathrm{~mA} \mathrm{~cm}^{-2}$, which is far superior to that of unary $\mathrm{Fe}$-doped $\mathrm{Fe}-\mathrm{Ni}_{2} \mathrm{P} @ \mathrm{MIL}-\mathrm{FeCoNi}$, MIL-FeCoNi precursor, bare $\mathrm{Ni}$ foam, and many recently reported non-noble metal-based catalysts (Table S3), affirming the indispensability of hetero-engineering and cation Co-doping on the enhancement of HzOR activity. The corresponding Tafel plot of FeCo$\mathrm{Ni}_{2} \mathrm{P} @$ MIL-FeCoNi is only $29 \mathrm{mV} \mathrm{dec}^{-1}$ (Fig. $3 \mathrm{~b}$ ), which is much lower than that of $\mathrm{Fe}^{-\mathrm{Ni}_{2}} \mathrm{P} @ \mathrm{MIL}-\mathrm{FeCoNi}\left(45 \mathrm{mV} \mathrm{dec}^{-1}\right)$, MILFeCoNi $\left(54 \mathrm{mV} \mathrm{dec}^{-1}\right)$, benchmark $\mathrm{RuO}_{2}\left(50 \mathrm{mV} \mathrm{dec}^{-1}\right)$, and $\mathrm{Ni}$ foam $\left(62 \mathrm{mV} \mathrm{dec}^{-1}\right)$, demonstrating the exceptional catalytic kinetics of $\mathrm{FeCo}-\mathrm{Ni}_{2} \mathrm{P} @ M I L-F e C o N i$ toward $\mathrm{HzOR}$. The LSV curves with different concentrations of $\mathrm{N}_{2} \mathrm{H}_{4}$ were also measured to check the intrinsic property of the catalytic activity for $\mathrm{FeCo}$ $\mathrm{Ni}_{2} \mathrm{P} @ M I L-F e C o N i$ toward HzOR. As shown in Fig. S13, the anodic current density increases sharply with the addition of hydrazine and continues to rise with increasing concentrations. Furthermore, to investigate the electrochemically active surface area (ECSA) in $0.5 \mathrm{~mol} \mathrm{~L}^{-1} \mathrm{~N}_{2} \mathrm{H}_{4}$ alkaline seawater electrolyte, we calculated the double layer capacitances $\left(C_{\mathrm{dl}}\right)$ to reflect the ECSA due to their proportional relationship (Figs S14 and S15) with the $\mathrm{FeCo}-\mathrm{Ni}_{2} \mathrm{P} @ M I L-F e C o N i$ electrode exhibiting the largest $C_{\mathrm{d}}$, consistent with its superior $\mathrm{HzOR}$ performance. To gain a better understanding of the interfacial charge-transfer kinetics, the electrochemical impedance spectroscopy (EIS) measurement was performed to obtain the Nyquist plots (Fig. S16), which show that the $\mathrm{FeCo}-\mathrm{Ni}_{2} \mathrm{P} @ \mathrm{MIL}-\mathrm{FeCoNi}$ with the smallest semicircle has the lowest charge-transfer resistance $\left(R_{\mathrm{ct}}\right)$ compared with other samples, revealing the outstanding interfacial electron-transfer kinetics between the electrode and electrolyte during the $\mathrm{HzOR}$ process. The long-term durability of FeCo$\mathrm{Ni}_{2} \mathrm{P} @ M I L-F e C o N i$ was measured using successive cyclic voltammetry $(\mathrm{CV})$ and the current density-time $(i-t)$ test, as the
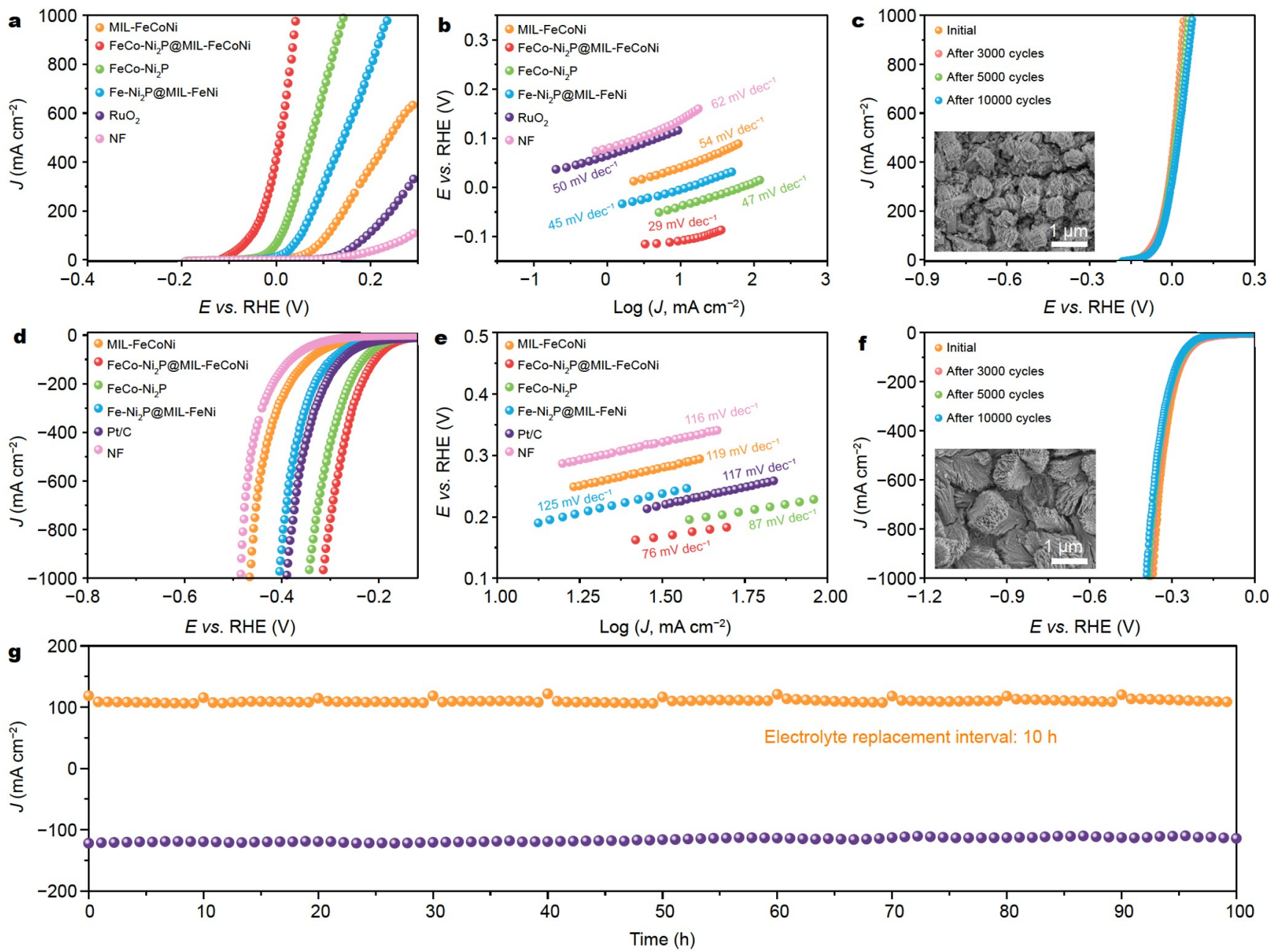

Figure 3 Electrocatalytic activity towards $\mathrm{HzOR}$ in $1.0 \mathrm{~mol} \mathrm{~L}^{-1} \mathrm{KOH}+0.5 \mathrm{~mol} \mathrm{~L}^{-1} \mathrm{~N}_{2} \mathrm{H}_{4}$ seawater electrolyte and $\mathrm{HER}$ in 1.0 mol L $\mathrm{KOH}^{-1}$ seawater electrolyte. (a) Polarization curves of different catalysts toward HzOR, and (b) the corresponding Tafel plots. (c) LSV curves of FeCo-Ni ${ }_{2} \mathrm{P} @ \mathrm{MIL}-\mathrm{FeCoNi}$ after different CV cycles toward HzOR. The inset is the post-HzOR SEM characterization. (d) Polarization curves of different catalysts toward HER, and (e) the corresponding Tafel plots. (f) LSV curves of FeCo-Ni 2 P@MIL-FeCoNi after different CV cycles toward HER. The inset is the post-HER SEM characterization. (g) $i$ - $t$ test for FeCo-Ni ${ }_{2} \mathrm{P} @ \mathrm{MIL}-\mathrm{FeCoNi}$ toward $\mathrm{HzOR}$ (top) recorded at the work potential of $120 \mathrm{mV}$ and $\mathrm{HER}$ (bottom) at the work potential of $270 \mathrm{mV}$. 
stability is critical for industrial applications of the electrocatalyst in seawater. To begin, the LSV curves and Nyquist plots of FeCo-Ni ${ }_{2}$ P@MIL-FeCoNi after 3000, 5000, and 10,000 cycles are nearly identical to the initial state (Fig. $3 \mathrm{c}$ and Fig. S17), and the post-HzOR characterizations (inset of Fig. 3c) demonstrate that the well-dispersed nanosheet arrays of the FeCo$\mathrm{Ni}_{2}$ P@MIL-FeCoNi can be well preserved after the HzOR test. Furthermore, the $i$ - $t$ test was performed at a potential of $120 \mathrm{mV}$, and the electrolyte was changed every $10 \mathrm{~h}$ to rule out the effect of decreased hydrazine concentration during the reaction. The current density could be retained as high as $100 \mathrm{~mA} \mathrm{~cm}^{-2}$ for at least $100 \mathrm{~h}$ without visible decay (Fig. $3 \mathrm{~g}$ ), both of which confirm the remarkable long-term stability, revealing robust durability of the $\mathrm{FeCo}-\mathrm{Ni}_{2} \mathrm{P} @ \mathrm{MIL}-\mathrm{FeCoNi}$ electrode during $\mathrm{HzOR}$ electrochemical tests. The XPS spectra were obtained to further investigate the compositional evolution following $\mathrm{HzOR}$ catalysis (Fig. S18). We found that the binding energies of $\mathrm{Fe}, \mathrm{Co}$, and $\mathrm{Ni}$ did not change significantly after the $\mathrm{HzOR}$ test. These results show that $\mathrm{FeCo}-\mathrm{Ni}_{2} \mathrm{P} @ \mathrm{MIL}-\mathrm{FeCoNi}$ could act as the active species for $\mathrm{HzOR}$ without causing any surface changes during the catalytic process.

We also tested the HER activity of the prepared catalysts in $1.0 \mathrm{~mol} \mathrm{~L}^{-1} \mathrm{KOH}$ seawater electrolyte, and the HER polarization curves are shown in Fig. 3d. The FeCo-Ni ${ }_{2} \mathrm{P} @ M I L-F e C o N i$ electrode exhibits remarkable enhancement for HER activity. To achieve cathodic current densities of 100 and $1000 \mathrm{~mA} \mathrm{~cm}^{-2}$, FeCo- $\mathrm{Ni}_{2} \mathrm{P} @ \mathrm{MIL}-\mathrm{FeCoNi}$ requires ultralow overpotentials of 210 and $310 \mathrm{mV}$. The corresponding Tafel plots (Fig. 3e) show that the Tafel slope of $\mathrm{FeCo}-\mathrm{Ni}_{2} \mathrm{P} @ \mathrm{MIL}-\mathrm{FeCoNi}$ is only $76 \mathrm{mV} \mathrm{dec}{ }^{-1}$, which is significantly lower than that of $\mathrm{FeCo}-\mathrm{Ni}_{2} \mathrm{P}$

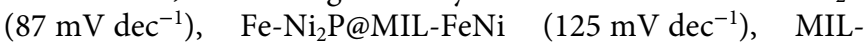
FeCoNi $\left(119 \mathrm{mV} \mathrm{dec}^{-1}\right), \mathrm{Pt} / \mathrm{C}\left(117 \mathrm{mV} \mathrm{dec}^{-1}\right)$, and $\mathrm{Ni}$ foam $\left(116 \mathrm{mV} \mathrm{dec}^{-1}\right)$, indicating the faster charge-transfer kinetics toward HER. In addition, to further investigate the outstanding activity, the $C_{\mathrm{dl}}$ and EIS of prepared electrodes in alkaline natural seawater electrolyte were measured, with the FeCo-Ni $\mathrm{N}_{2} \mathrm{P} @ \mathrm{MIL}-$ FeCoNi electrode exhibiting the highest $C_{\mathrm{dl}}$ (Figs S19 and S20) and the lowest charge-transfer resistance $\left(R_{\mathrm{ct}}\right)$ (Fig. S21), consistent with its superior HER performance. Fig. 3f shows the comparison of LSV curves after 3000, 5000, and 10,000 cycles of $\mathrm{CV}$ test with the initial one, and the nearly overlapped LSV curves and unchanged nanosheet array morphology (inset of Fig. 3f) reveal the remarkable stability of $\mathrm{FeCo}-\mathrm{Ni}_{2} \mathrm{P} @ M I L-$ FeCoNi. Furthermore, the corresponding charge-transfer resistance $\left(R_{\mathrm{ct}}\right)$ shows negligible changes (Fig. S22), implying the integrated electrode's structural robustness. Furthermore, during the 100-hour chronoamperometric $i$ - $t$ test, nearly $100 \%$ current density retention was observed at the working potential of $270 \mathrm{mV}$ (Fig. 3g), indicating the excellent long-term stability of the FeCo-Ni ${ }_{2} \mathrm{P} @ M I L-F e C o N i$ catalyst. These findings suggest that the $\mathrm{FeCo}-\mathrm{Ni}_{2} \mathrm{P} @ \mathrm{MIL}-\mathrm{FeCoNi}$ heterostructure can endow the material with superior HER activity by significantly improving the FeCo- $\mathrm{Ni}_{2} \mathrm{P} @ \mathrm{MIL}-\mathrm{FeCoNi}$ intrinsic activity. After the HER test, the binding energy of $\mathrm{Ni} 2 \mathrm{p}$ in $\mathrm{FeCo}-\mathrm{Ni}_{2} \mathrm{P} @ \mathrm{MIL}-$ FeCoNi shifts to lower binding energy $(\triangle \mathrm{BE}=1.3 \mathrm{eV}$, Fig. S23), which is also reflected in the negative shift of Co $2 p$ and Fe $2 p$, primarily caused by the partial reduction of $\mathrm{MO}_{6}$ units in MOFs to $\mathrm{M} / \mathrm{MO}_{6}$ clusters in the HER process. Among them, the $\mathrm{NiO}_{6}$ unit can effectively cleave the $\mathrm{HO}-\mathrm{H}$ bond (Volmer step) to provide $\mathrm{H}^{*}$; thus, the lower $\mathrm{Fe} / \mathrm{Co} / \mathrm{Ni}$ binding energies in $\mathrm{FeCo}-$ $\mathrm{Ni}_{2} \mathrm{P} @$ MIL-FeCoNi after HER imply not only longer $\mathrm{M}-\mathrm{O}$ bonds $(\mathrm{M}=\mathrm{Fe}, \mathrm{Co}, \mathrm{Ni})$, but also weaker binding energies, all of which can promote hydrogen bonding in alkaline seawater media to deeply accelerate the reaction kinetics [24].

Investigation on the $\mathrm{OHzS}$ performance in a two-electrode system Based on the superior catalytic $\mathrm{HzOR}$ and HER performance of FeCo-Ni $\mathrm{N}_{2} \mathrm{P} @ \mathrm{MIL}-\mathrm{FeCoNi}$, a two-electrode OHzS electrolyzer (Fig. 4a) was assembled with FeCo- $\mathrm{Ni}_{2} \mathrm{P} @ \mathrm{MIL}-\mathrm{FeCoNi}$ as both anode and cathode. The LSV curves (Fig. 4b) show that the FeCo-Ni $\mathrm{N}_{2} \mathrm{P} @ \mathrm{MIL}-\mathrm{FeCoNi}$ couple has a better catalytic performance than the $\mathrm{Pt} / \mathrm{C} \| \mathrm{RuO}_{2}$ couple. Specifically, the FeCo$\mathrm{Ni}_{2} \mathrm{P} @ M I L-F e C o N i$ couple requires only an ultrasmall cell voltage of 242 and $400 \mathrm{mV}$ to achieve 100 and $1000 \mathrm{~mA} \mathrm{~cm}^{-2}$, which are much lower than the $\mathrm{Pt} / \mathrm{C} \| \mathrm{RuO}_{2}$ couple and outperform most highly active non-noble electrocatalysts (Fig. 4c). Table S4 provides a detailed comparison with various bifunctional catalysts. One of the most important factors in determining whether electrocatalysts have industrial application prospects is stability. The multistep chronoamperometric measurement by a peristaltic pump is shown in Fig. $4 \mathrm{~d}$ and Movie $\mathrm{S} 1$. As we can see, the current densities increased gradually as the overpotential increased stepwise, and the reversed process's current densities were consistent with the forward process, indicating excellent overall stability. Furthermore, we performed an $i$ - $t$ test for $\mathrm{FeCo}-\mathrm{Ni}_{2} \mathrm{P} @ \mathrm{MIL}-\mathrm{FeCoNi}$ for $\mathrm{OHzS}$ in a seawater system to maintain the large current density of 100 and $500 \mathrm{~mA} \mathrm{~cm}^{-2}$ (Fig. S24 and Fig. 4e), and electrolyte was replaced through the circulation device to eliminate the influence of hydrazine concentration decrease. The electrode exhibits remarkable stability at high current density for a continuous $1000 \mathrm{~h}$, demonstrating excellent durability in seawater for twoelectrode $\mathrm{OHzS}$.

\section{Extended application of FeCo-Ni ${ }_{2} \mathrm{P} @ \mathrm{MIL}-\mathrm{FeCoNi}$ for energy- saving hydrogen production}

Notably, the feasibility of energy-saving hydrogen production with $\mathrm{FeCo}-\mathrm{Ni}_{2} \mathrm{P} @ \mathrm{MIL}-\mathrm{FeCoNi}$ as bifunctional electrocatalyst via $\mathrm{OHzS}$ in a seawater system was confirmed. Fig. 5a compares the LSV curves of OHzS in $1.0 \mathrm{~mol} \mathrm{~L}^{-1} \mathrm{KOH}+0.5 \mathrm{~mol} \mathrm{~L}^{-1} \mathrm{~N}_{2} \mathrm{H}_{4}$ seawater and OWS in $1.0 \mathrm{~mol} \mathrm{~L}^{-1} \mathrm{KOH}$ seawater, revealing a significant improvement in energy efficiency. In particular, the $\mathrm{OHzS}$ in the seawater system requires only $242,277,327$, and $400 \mathrm{mV}$ to reach $100,200,500$, and $1000 \mathrm{~mA} \mathrm{~cm}^{-2}$, respectively, whereas those in the OWS system require 1.65, 1.76, 1.83, and $1.87 \mathrm{~V}$ (Fig. S25). Furthermore, Faradaic efficiency was measured as an intuitive parameter to evaluate catalytic performance using the water drainage method in an H-type electrolytic cell with $1.0 \mathrm{~mol} \mathrm{~L}^{-1} \mathrm{KOH}+0.5 \mathrm{~mol} \mathrm{~L}^{-1} \mathrm{~N}_{2} \mathrm{H}_{4}$ seawater as the electrolyte. The electrolyte in the electrolytic cell is separated by a Nafion membrane, as shown in Fig. 5b, and the drastic $\mathrm{H}_{2}$ and $\mathrm{N}_{2}$ bubbles can be seen on the surface of $\mathrm{FeCo}-\mathrm{Ni}_{2} \mathrm{P} @ \mathrm{MIL}-$ FeCoNi catalysts (inset of Fig. 5b). Movie S2 depicts the water drainage process of the $\mathrm{OHzS}$ unit from $\mathrm{FeCo}-\mathrm{Ni}_{2} \mathrm{P} @ \mathrm{MIL}-$ FeCoNi. The volume of $\mathrm{H}_{2}$ and $\mathrm{N}_{2}$ produced by the FeCo$\mathrm{Ni}_{2} \mathrm{P} @$ MIL-FeCoNi pair is shown in Fig. 5 c. With a $\mathrm{H}_{2}$ to $\mathrm{N}_{2}$ volume ratio of 1.97:1 (Fig. 5d), the Faradaic efficiency is close to $100 \%$ for $\mathrm{OHzS}$, approaching the theoretical value of $2: 1$. We also measured the Faradaic efficiency in the OWS unit using $1.0 \mathrm{~mol} \mathrm{~L}^{-1} \mathrm{KOH}$ seawater as the electrolyte (Fig. S26), and the $\mathrm{H}_{2}$ to $\mathrm{O}_{2}$ volume ratio is $2.02: 1$ (Fig. S27), which is close to the theoretical value. The solar panel is an environmental protection 

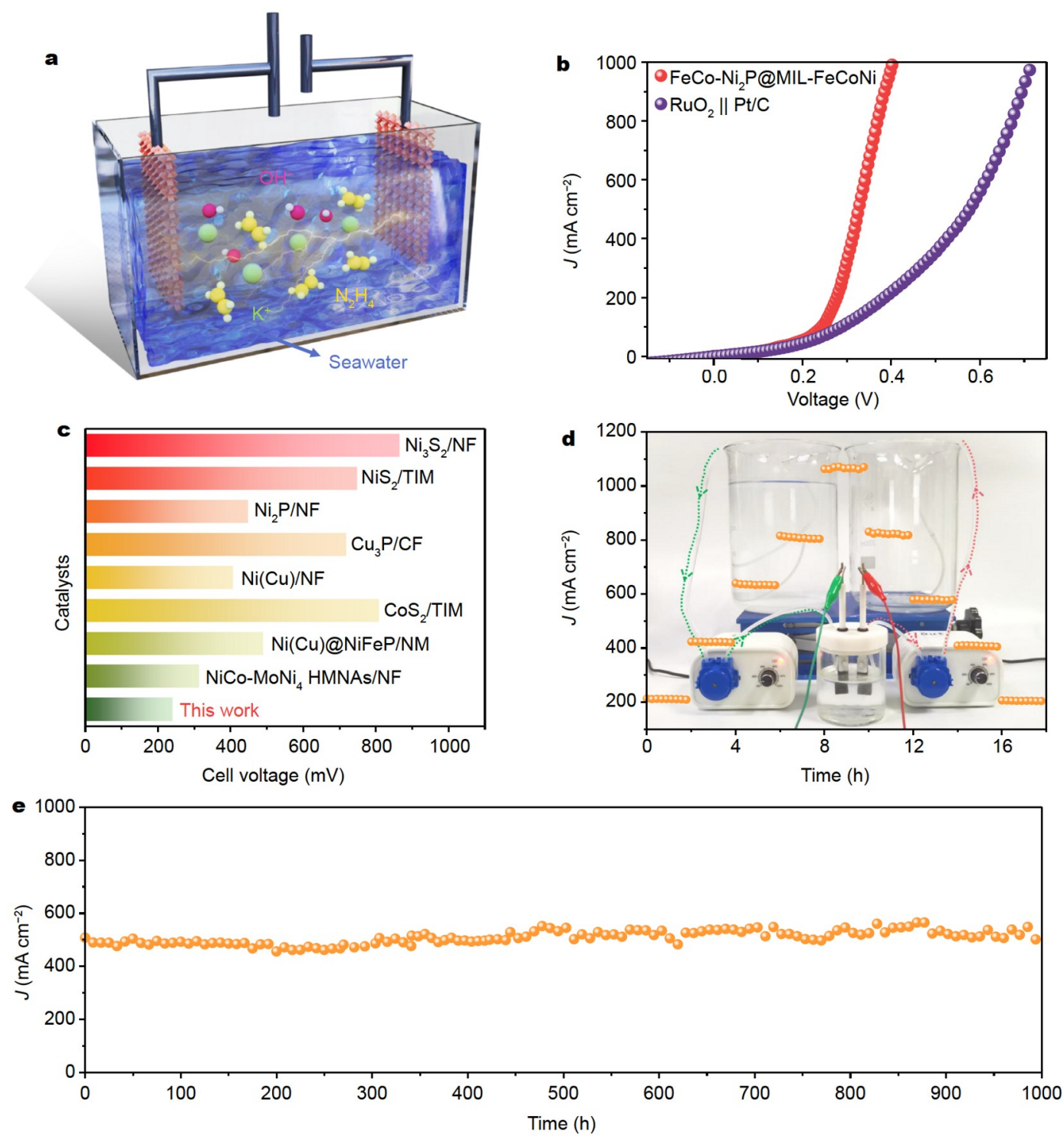

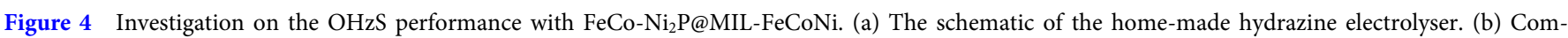
paring polarization curves of $\mathrm{RuO}_{2} \| \mathrm{Pt} / \mathrm{C}$ and $\mathrm{FeCo}-\mathrm{Ni}_{2} \mathrm{P} @ \mathrm{MIL}-\mathrm{FeCoNi}$ couples. (c) The cell voltage comparison of $\mathrm{FeCo}-\mathrm{Ni} \mathrm{i}_{2} \mathrm{P} @ \mathrm{MIL}-\mathrm{FeCoNi}$ with other materials to drive $100 \mathrm{~mA} \mathrm{~cm}^{-2}$. (d) Multistep chronoamperometric curves of FeCo- $\mathrm{Ni}_{2} \mathrm{P} @ \mathrm{MIL}-\mathrm{FeCoNi}$. (e) The $i-t$ curve of $\mathrm{OHzS}$ at $500 \mathrm{~mA} \mathrm{~cm}{ }^{-2}$ for $1000 \mathrm{~h}$.

device that uses natural solar energy to perform water electrolysis to generate hydrogen gas. Based on the results of the above experiments, the $\mathrm{OHzS}$ and OWS in seawater system using FeCo- $\mathrm{Ni}_{2} \mathrm{P} @ \mathrm{MIL}-\mathrm{FeCoNi}$ as both the anode and cathode were successfully powered by a solar panel. Surprisingly, in comparison with the small amount of $\mathrm{O}_{2}$ and $\mathrm{H}_{2}$ produced by OWS in the seawater system, the $\mathrm{N}_{2}$ and $\mathrm{H}_{2}$ produced by $\mathrm{OHzS}$ in the seawater system filled the entire green balloon (Fig. 5e and Movie S3). Theoretical calculations show that $\mathrm{OHzS}$ in a seawater system can save $3.03 \mathrm{~kW}$ h of power compared with OWS for $1.0 \mathrm{Nm}^{3}$ hydrogen preparation; the calculation process is detailed in the Supplementary information (Fig. $5 \mathrm{f}$ and Fig. S28). The above work demonstrates that FeCo- $\mathrm{Ni}_{2} \mathrm{P} @ \mathrm{MIL}-\mathrm{FeCoNi}$ arrays incorporating the benefits of hetero-engineering and cation Co-doping exhibit excellent HzOR and HER activity in alkaline seawater and can thus serve as a competent and longlasting electrocatalyst for energy-saving $\mathrm{H}_{2}$ production in an alkaline seawater system.

DFT calculations of FeCo- $\mathrm{Ni}_{2} \mathrm{P} @$ MIL-FeCoNi for HER and HzOR The DFT calculations were then carried out to demonstrate the synergistic effect of hetero-engineering and cation doping on the superior bifunctional activity of FeCo-Ni $\mathrm{F}_{2} \mathrm{P} @ \mathrm{MIL}-\mathrm{FeCoNi}$. Due to the small interfacial strain, the (201) facet of $\mathrm{Ni}_{2} \mathrm{P}$ and the (200) facet of MIL-FeCoNi for FeCo-Ni $\mathrm{N}_{2} \mathrm{P} / \mathrm{MIL}-\mathrm{FeCoNi}$ [36] are selected as the optimized models by XRD and HRTEM analysis (Fig. 6a). The theoretical models of $\mathrm{FeCo}-\mathrm{Ni}_{2} \mathrm{P}, \mathrm{MIL}-\mathrm{FeCoNi}$, and $\mathrm{Fe}_{-} \mathrm{Ni}_{2} \mathrm{P} @ \mathrm{MIL}-\mathrm{FeNi}$ were also illustrated for comparison (Fig. S29). The calculated adsorption energies of $\mathrm{H}_{2} \mathrm{O}$ are shown in Fig. $6 \mathrm{~b}$ because an ideal catalyst should have sufficient affinity to adsorb water to accelerate the electron-transfer process. In comparison with $\mathrm{FeCo}-\mathrm{Ni}_{2} \mathrm{P} \quad(-0.31 \mathrm{eV})$, MIL-FeCoNi $(-0.76 \mathrm{eV})$, and $\mathrm{Fe}_{-\mathrm{Ni}} \mathrm{P} @ \mathrm{MIL}-\mathrm{FeNi} \quad(-1.04 \mathrm{eV})$, FeCo$\mathrm{Ni}_{2} \mathrm{P} @ M I L-F e C o N i$ has a strong adsorption energy of $-1.32 \mathrm{eV}$, 


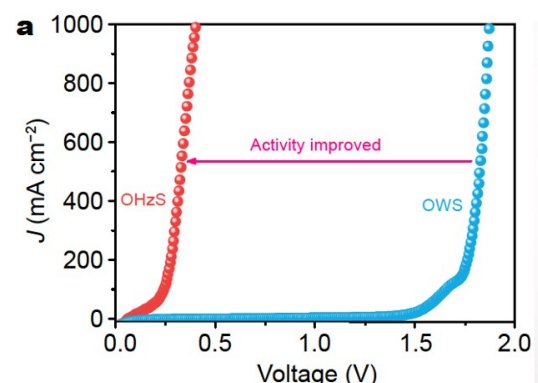

b
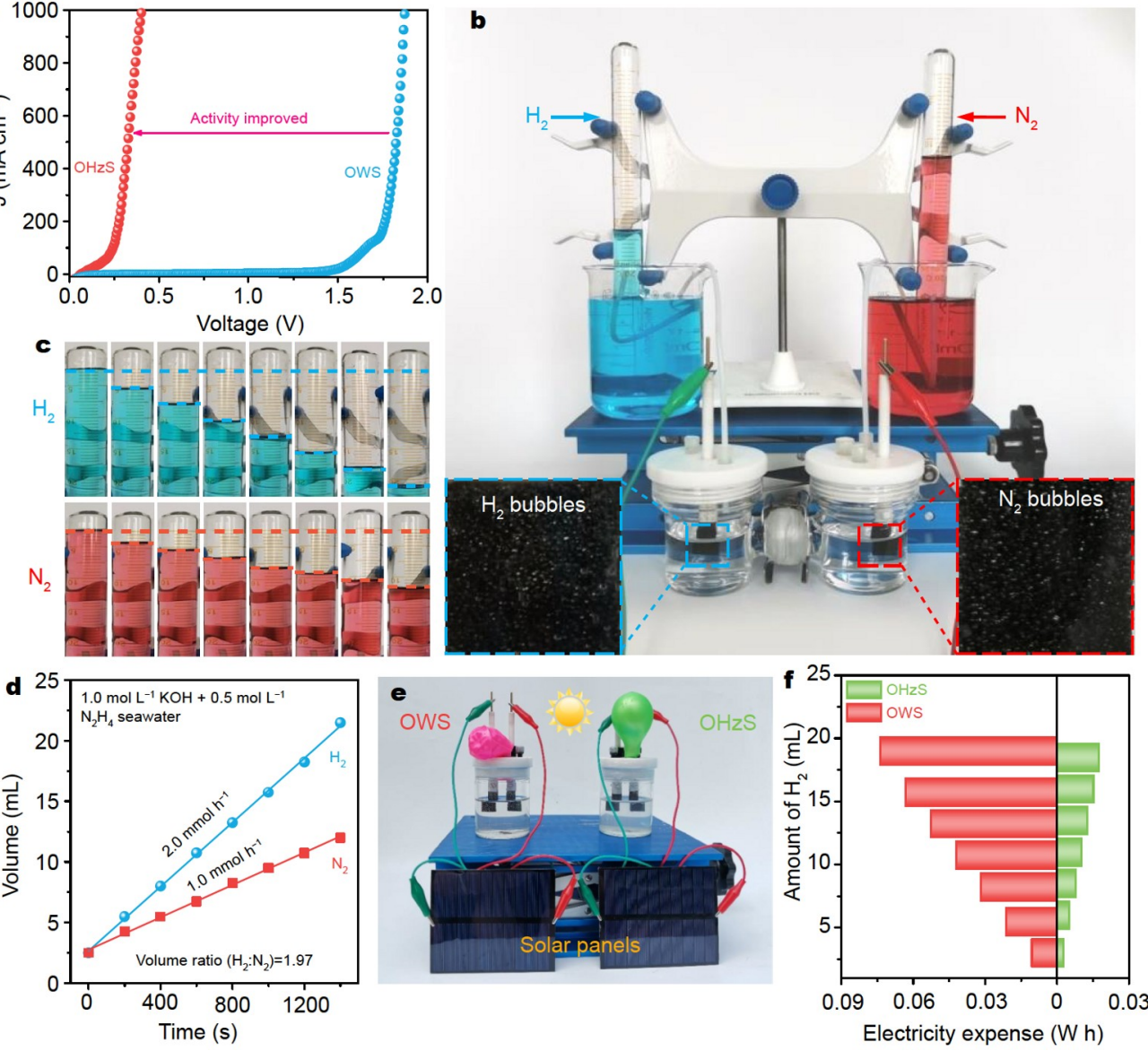

Figure 5 Illustration of energy-saving hydrogen production using FeCo- $\mathrm{Ni}_{2} \mathrm{P} @ M I L-F e C o N i$ electrode. (a) LSV curves for OHzS and OWS. (b) Faradaic efficiency measurement device based on water splitting, and the inset is the photographs of $\mathrm{H}_{2}$ bubbles and $\mathrm{N}_{2}$ bubbles attached to FeCo-Ni $2 \mathrm{P} @ \mathrm{MIL}-\mathrm{FeCoNi}$ electrode. (c) Photographs of $\mathrm{H}_{2}$ and $\mathrm{N}_{2}$ collected at different times. (d) The amount of $\mathrm{H}_{2}$ and $\mathrm{N}_{2}$ varying with time. (e) Image of the electrocatalytic process powered by the solar panels. (f) The power consumption varying with the amount of $\mathrm{H}_{2}$.

indicating that $\mathrm{H}_{2} \mathrm{O}$ molecule adsorption is energetically more favorable on the FeCo- $\mathrm{Ni}_{2} \mathrm{P} @ \mathrm{MIL}-\mathrm{FeCoNi}$ surface. Water dissociation in alkaline media can provide useful information about the qualitative trend of HER activity. Fig. S30 depicts the optimized transition barrier structures for $\mathrm{H}_{2} \mathrm{O}$ dissociation in all samples. The fast HER kinetics in alkaline solution is caused by the low kinetic energy barrier of water dissociation on the catalyst surface; the calculated water dissociation energies on these surfaces are shown in Fig. 6c. As expected, FeCo-Ni ${ }_{2} \mathrm{P} @ M I L-$ $\mathrm{FeCoNi}$ has a lower energy barrier of the transition state $(0.60 \mathrm{eV})$ than $\mathrm{FeCo}-\mathrm{Ni}_{2} \mathrm{P}(0.87 \mathrm{eV})$, MIL-FeCoNi $(0.80 \mathrm{eV})$, and $\mathrm{Fe}_{-} \mathrm{Ni}_{2} \mathrm{P} @ \mathrm{MIL}-\mathrm{FeCoNi}(0.70 \mathrm{eV})$, indicating that FeCo$\mathrm{Ni}_{2} \mathrm{P} @$ MIL-FeCoNi has fast reaction kinetics for water dissociation and thus guarantees effective water dissociation. It is widely accepted that the free energy of adsorbed $\mathrm{H}\left(\Delta G_{\mathrm{H}^{*}}\right)$ is a critical indicator of HER performance in the following HER process and the ideal $\Delta G_{\mathrm{H}^{*}}$ should be more thermoneutral. As a result, optimized models for $\mathrm{H}^{*}$ adsorption sites on electrocatalysts were presented to infer the possible hydrogen adsorption site, where different sites such as $\mathrm{Fe}, \mathrm{Co}, \mathrm{Ni}$, and $\mathrm{P}$ were considered (see Fig. S31). The results show that the site with the shortest distance between $\mathrm{H}$ and the nearest $\mathrm{Ni}$ atom is the favorable site for hydrogen adsorption and has the most ideal $\Delta G_{\mathrm{H}^{*}}$ value. Particularly, the $\Delta G_{\mathrm{H}^{*}}$ value of the constructed FeCo-Ni ${ }_{2} \mathrm{P} @ \mathrm{MIL}-\mathrm{FeCoNi}$ heterogeneous interface is close to the thermoneutral value $(-0.10 \mathrm{eV})$ compared with $\mathrm{Fe}-\mathrm{Ni}_{2} \mathrm{P} @ \mathrm{MIL}-$ FeNi $(-0.20 \mathrm{eV})$, MIL-FeCoNi $(-0.22 \mathrm{eV})$, and FeCo- $\mathrm{Ni}_{2} \mathrm{P}$ $(-0.25 \mathrm{eV})$ (Fig. 6d), which demonstrates that Co-doping and hetero-engineering can synergistically optimize hydrogen evolution kinetics and further improve the intrinsic catalytic activity for HER. The density of states (DOS) values of each element in FeCo- $\mathrm{Ni}_{2} \mathrm{P}, \quad \mathrm{MIL}-\mathrm{FeCoNi}, \quad \mathrm{Fe}-\mathrm{Ni}_{2} \mathrm{P} @ \mathrm{MIL}-\mathrm{FeNi}$, and FeCo$\mathrm{Ni}_{2} \mathrm{P} @$ MIL-FeCoNi are shown in Fig. S32, and the results show that the Ni element contributes the most to the DOS. The DOS of $\mathrm{FeCo}-\mathrm{Ni}_{2} \mathrm{P} @ \mathrm{MIL}-\mathrm{FeCoNi}$ near the Fermi level is continuous and has no evident gap, demonstrating the metallic property of FeCo-Ni ${ }_{2} \mathrm{P} @ M I L-F e C o N i$ (Fig. 6e). The DOS of FeCo$\mathrm{Ni}_{2} \mathrm{P} @ M I L-F e C o N i$ at the Fermi level is obviously increased after forming the $\mathrm{FeCo}-\mathrm{Ni}_{2} \mathrm{P} / \mathrm{MIL}-\mathrm{FeCoNi}$ heterogeneous structure, implying that more charge carriers are involved in the catalytic reaction and the catalytic performance could be significantly improved. Furthermore, the increased DOS at the Fermi level in the heterogeneous interface improves electrical conductivity with fast interfacial electron-transfer kinetics. Fig. 6e also shows the projected DOS of the d band of the FeCo$\mathrm{Ni}_{2} \mathrm{P}, \mathrm{MIL}-\mathrm{FeCoNi}, \mathrm{Fe}-\mathrm{Ni}_{2} \mathrm{P} @ \mathrm{MIL}-\mathrm{FeNi}$, and FeCo-Ni $\mathrm{F}_{2} \mathrm{P} @ \mathrm{MIL}-$ FeCoNi models, with d-band centers at $-1.05,-1.18,-1.76$, and $-2.47 \mathrm{eV}$, respectively. The left shift of DOS reveals that the distribution of d-band electrons is far away from the Fermi level, indicating that the catalyst has a lower activity to form chemical 

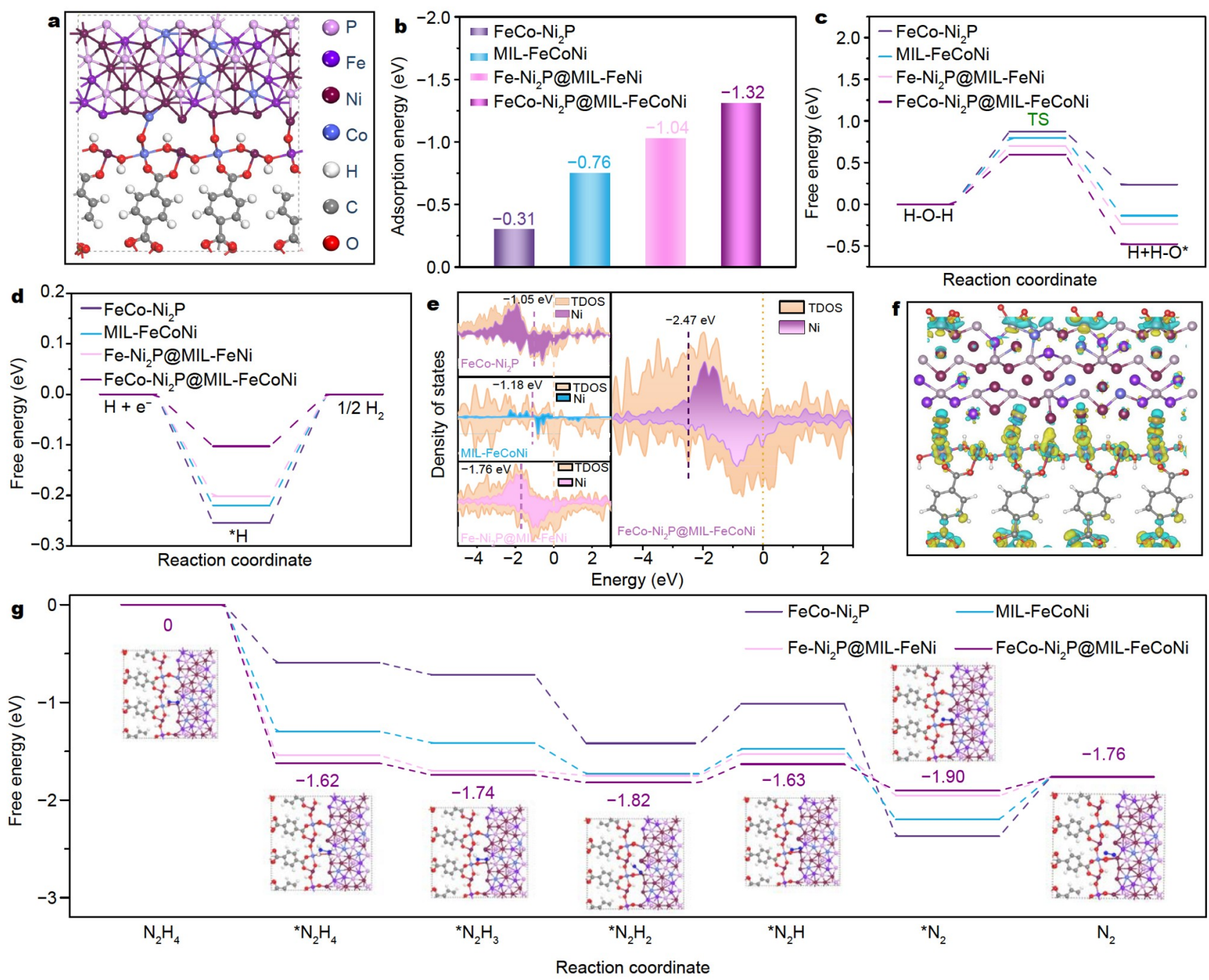

Figure 6 DFT-relaxed structure models of FeCo- $\mathrm{Ni}_{2} \mathrm{P} @ \mathrm{MIL}-\mathrm{FeCoNi}$ and the calculated profiles of free energy for HER and HzOR. (a) Top-view image of the FeCo-Ni 2 P@MIL-FeCoNi unit cell. (b) Water adsorption energy. (c) Transition barrier for $\mathrm{H}_{2} \mathrm{O}$ dissociation on surface. (d) Free energy profiles of HER for

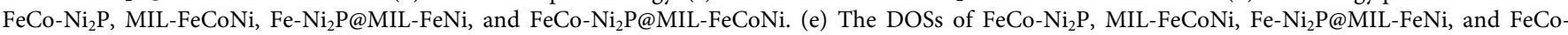
$\mathrm{Ni}_{2} \mathrm{P} @ M I L-F e C o N i .(f)$ Charge density difference of FeCo-Ni $2 \mathrm{P} @ M I L-F e C o N i$ with the blue region representing charge depletion and the yellow region representing charge accumulation. The iso-values are $0.06 \mathrm{e} \AA^{-3}$. (g) Reaction pathways and the corresponding energy changes of $\mathrm{HzOR}$ for FeCo- $\mathrm{Ni}_{2} \mathrm{P} @ \mathrm{MIL}$ $\mathrm{FeCoNi}$ as well as the free energy profiles of $\mathrm{HzOR}$ on the FeCo-Ni $2 \mathrm{P}, \mathrm{MIL}-\mathrm{FeCoNi}, \mathrm{Fe}-\mathrm{Ni}_{2} \mathrm{P} @ \mathrm{MIL}-\mathrm{FeNi}$, and FeCo-Ni $2 \mathrm{P} @ \mathrm{MIL}-\mathrm{FeCoNi}$ surfaces.

bonds with other species, resulting in a decrease in adsorption energy, which is beneficial to the desorption of the adsorbed hydrogen. The charge density difference analysis (Fig. 6f) shows that the electron localization behavior upon Co dopant can be revealed, with obvious charge depletion (blue color) on $\mathrm{Ni}$ atoms in $\mathrm{FeCo}-\mathrm{Ni}_{2} \mathrm{P}$, while the $\mathrm{H}$ on the carboxyl group has charge accumulation (yellow color). Furthermore, charge redistribution is primarily restricted on the $\mathrm{FeCo}-\mathrm{Ni}_{2} \mathrm{P} / \mathrm{MIL}-\mathrm{FeCoNi}$ interface, and charges are transferred from the $\mathrm{FeCo}-\mathrm{Ni}_{2} \mathrm{P}$ to the MIL$\mathrm{FeCoNi}$, which may be due to electronic interaction between the $\mathrm{FeCo}-\mathrm{Ni}_{2} \mathrm{P}$ and the MIL-FeCoNi.

DFT calculations of $\mathrm{HzOR}$ activity for $\mathrm{FeCo}-\mathrm{Ni}_{2} \mathrm{P}$, MIL$\mathrm{FeCoNi}, \mathrm{Fe}_{-} \mathrm{Ni}_{2} \mathrm{P} @ \mathrm{MIL}-\mathrm{FeNi}$, and FeCo-Ni ${ }_{2} \mathrm{P} @ \mathrm{MIL}-\mathrm{FeCoNi}$ were also performed, which is useful for interpreting the synergy effect of Co-doping and hetero-engineering on $\mathrm{HzOR}$ catalytic activity. Fig. S33 depicts $\mathrm{FeCo}-\mathrm{Ni}_{2} \mathrm{P} @ M I L-F e C o N i$ models simulating $\mathrm{N}_{2} \mathrm{H}_{4}$ molecule adsorption. The molecular distance between $\mathrm{N}_{2} \mathrm{H}_{4}$ and the nearest neighboring $\mathrm{Ni}$ atom is $1.84 \AA$, which is much smaller than the distance between $\mathrm{N}_{2} \mathrm{H}_{4}$ and other atoms. This means that the $\mathrm{Ni}$ atom promotes $\mathrm{N}_{2} \mathrm{H}_{4}$ adsorption. Fig. $6 \mathrm{~g}$ depicts the Gibbs free energy from $\mathrm{N}_{2} \mathrm{H}_{4}$ to $\mathrm{N}_{2}$ (the stepwise dehydrogenation process) with solvent interactions on $\mathrm{FeCo}-\mathrm{Ni}_{2} \mathrm{P}, \mathrm{MIL}-\mathrm{FeCoNi}, \mathrm{Fe}-\mathrm{Ni}_{2} \mathrm{P} @ \mathrm{MIL}-\mathrm{FeNi}$, and FeCo- $\mathrm{Ni}_{2} \mathrm{P} @ \mathrm{MIL}-\mathrm{FeCoNi}$, respectively, and the detailed values of each dehydrogenation step are presented (Table S5). The adsorption of $\mathrm{N}_{2} \mathrm{H}_{4}$ is particularly thermodynamically favorable on the surface of $\mathrm{FeCo}-\mathrm{Ni}_{2} \mathrm{P} @ \mathrm{MIL}-\mathrm{FeCoNi}(-1.62 \mathrm{eV})$ and $\mathrm{Fe}-$ $\mathrm{Ni}_{2} \mathrm{P} @ M I L-F e N i(-1.54 \mathrm{eV})$. Notably, the rate determining step for $\mathrm{FeCo}-\mathrm{Ni}_{2} \mathrm{P}$ and MIL-FeCoNi surfaces toward $\mathrm{HzOR}$ is the dehydrogenation of $* \mathrm{~N}_{2}$ to $\mathrm{N}_{2}$. When we build a FeCo$\mathrm{Ni}_{2} \mathrm{P} @ M I L-F e C o N i$ heterostructure, the rate determining steps are changed to the dehydrogenation of $* \mathrm{~N}_{2} \mathrm{H}_{2}$ to $* \mathrm{~N}_{2} \mathrm{H}$, and the energy barrier is reduced to $0.19 \mathrm{eV}$, whereas the energy barriers for $\mathrm{FeCo}-\mathrm{Ni}_{2} \mathrm{P}, \mathrm{Fe}-\mathrm{Ni}_{2} \mathrm{P} @ \mathrm{MIL}-\mathrm{FeNi}$, and MIL-FeCoNi are 0.61, 0.22 , and $0.44 \mathrm{eV}$, respectively, demonstrating that the FeCo$\mathrm{Ni}_{2} \mathrm{P} @ M I L-F e C o N i$ with the Co-doping and hetero-engineering 
can achieve the tremendous change and enhancement of the dehydrogenation kinetics. The results show that the addition of Co and the formation of heterogeneous interfaces can improve the thermodynamic behavior of water dissociation and hydrogen adsorption for HER and the dehydrogenation process for $\mathrm{HzOR}$.

\section{CONCLUSIONS}

In summary, we have synthesized an in-situ grown Fe/Co dualdoped $\mathrm{Ni}_{2} \mathrm{P}$ and MIL-FeCoNi heterostructure arrays on $\mathrm{Ni}$ foam (FeCo-Ni ${ }_{2} \mathrm{P} @ \mathrm{MIL}-\mathrm{FeCoNi}$ ), which possess outstanding bifunctional electrocatalytic activities toward $\mathrm{HzOR}$ and $\mathrm{HER}$ in alkaline natural seawater medium due to the synergistic effect of hetero-engineering and cation doping. It can achieve an impressive industrial-level current density of $1000 \mathrm{~mA} \mathrm{~cm}^{-2}$ at an ultralow working potential of $42 \mathrm{mV}$ toward $\mathrm{HzOR}$ and an overpotential of $310 \mathrm{mV}$ toward HER. Importantly, the assembled FeCo-Ni ${ }_{2} \mathrm{P} @ M I L-F e C o N i$ for $\mathrm{OHzS}$ in seawater system requires a much lower cell voltage of 244 and $400 \mathrm{mV}$, respectively, to reach 100 and $1000 \mathrm{~mA} \mathrm{~cm}^{-2}$, and with excellent longterm durability for $1000 \mathrm{~h}$ to maintain above $500 \mathrm{~mA} \mathrm{~cm}^{-2}$ and nearly $100 \%$ Faradaic efficiency. Furthermore, as a proof-ofconcept, energy-saving $\mathrm{H}_{2}$ production systems utilizing the $\mathrm{OHzS}$ unit can save $3.03 \mathrm{~kW}$ h of electricity when producing $1.0 \mathrm{Nm}^{3}$ of $\mathrm{H}_{2}$, propelling the efficient utilization of hydrogen reserved with unlimited abundance in the ocean energy field for approaching carbon-neutral hydrogen economy. The DFT calculations provide the theoretical foundation for improved HER and $\mathrm{HzOR}$ performance, in which Co-doping and the construction of $\mathrm{FeCo}-\mathrm{Ni}_{2} \mathrm{P}$ and MIL-FeCoNi heterointerfaces can lower the water dissociation barrier, optimize hydrogen adsorption free energy $\left(\Delta G_{H^{*}}\right)$ toward HER, and lower the activation energy of the dehydrogenation process toward $\mathrm{HzOR}$.

\section{Received 26 October 2021; accepted 9 December 2021; published online 9 February 2022}

1 Wu Y, Tao X, Qing Y, et al. Cr-doped FeNi-P nanoparticles encapsulated into $\mathrm{N}$-doped carbon nanotube as a robust bifunctional catalyst for efficient overall water splitting. Adv Mater, 2019, 31: 1900178

2 Yan $\mathrm{H}, \mathrm{Xie} \mathrm{Y}, \mathrm{Wu} \mathrm{A}$, et al. Anion-modulated HER and OER activities of 3D Ni-V-based interstitial compound heterojunctions for high-efficiency and stable overall water splitting. Adv Mater, 2019, 31: 1901174

3 Wu Y, Wang $\mathrm{H}$, Ji S, et al. Engineered porous $\mathrm{Ni}_{2} \mathrm{P}$-nanoparticle/ $/ \mathrm{Ni}_{2} \mathrm{P}$ nanosheet arrays via the Kirkendall effect and Ostwald ripening towards efficient overall water splitting. Nano Res, 2020, 13: 2098-2105

4 Song C, Liu Y, Wang Y, et al. Highly efficient oxygen evolution and stable water splitting by coupling NiFe LDH with metal phosphides. Sci China Mater, 2021, 64: 1662-1670

5 Gao WK, Yang M, Chi JQ, et al. In situ construction of surface defects of carbon-doped ternary cobalt-nickel-iron phosphide nanocubes for efficient overall water splitting. Sci China Mater, 2019, 62: 1285-1296

6 Jin H, Wang X, Tang C, et al. Stable and highly efficient hydrogen evolution from seawater enabled by an unsaturated nickel surface nitride. Adv Mater, 2021, 33: 2007508

7 Wang C, Zhu M, Cao Z, et al. Heterogeneous bimetallic sulfides based seawater electrolysis towards stable industrial-level large current density. Appl Catal B-Environ, 2021, 291: 120071

8 Feng W, Chen $\mathrm{H}$, Zhang $\mathrm{Q}$, et al. Lanthanide-regulated oxygen evolution activity of face-sharing $\mathrm{IrO}_{6}$ dimers in 6H-perovskite electrocatalysts. Chin J Catal, 2020, 41: 1692-1697

9 Tao L, Guo P, Zhu W, et al. Highly efficient mixed-metal spinel cobaltite electrocatalysts for the oxygen evolution reaction. Chin J Catal, 2020, 41: 1855-1863
10 Li X, Xue W, Mo R, et al. In situ growth of minimal Ir-incorporated $\mathrm{Co}_{x} \mathrm{Ni}_{1-x} \mathrm{O}$ nanowire arrays on $\mathrm{Ni}$ foam with improved electrocatalytic activity for overall water splitting. Chin J Catal, 2019, 40: 1576-1584

11 Yu L, Zhu Q, Song S, et al. Non-noble metal-nitride based electrocatalysts for high-performance alkaline seawater electrolysis. Nat Commun, 2019, 10: 5106

12 Zang W, Sun T, Yang T, et al. Efficient hydrogen evolution of oxidized $\mathrm{Ni}-\mathrm{N}_{3}$ defective sites for alkaline freshwater and seawater electrolysis. Adv Mater, 2021, 33: 2003846

13 Wu L, Yu L, Zhang F, et al. Heterogeneous bimetallic phosphide $\mathrm{Ni}_{2} \mathrm{P}$ $\mathrm{Fe}_{2} \mathrm{P}$ as an efficient bifunctional catalyst for water/seawater splitting. Adv Funct Mater, 2021, 31: 2006484

14 Liu G, Sun Z, Zhang X, et al. Vapor-phase hydrothermal transformation of a nanosheet array structure $\mathrm{Ni}(\mathrm{OH})_{2}$ into ultrathin $\mathrm{Ni}_{3} \mathrm{~S}_{2}$ nanosheets on nickel foam for high-efficiency overall water splitting. J Mater Chem A, 2018, 6: 19201-19209

15 Li Y, Zhang J, Liu Y, et al. Partially exposed $\mathrm{RuP}_{2}$ surface in hybrid structure endows its bifunctionality for hydrazine oxidation and hydrogen evolution catalysis. Sci Adv, 2020, 6: b4197

16 Li Y, Li J, Qian Q, et al. Superhydrophilic Ni-based multicomponent nanorod-confined-nanoflake array electrode achieves waste-batterydriven hydrogen evolution and hydrazine oxidation. Small, 2021, 17: 2008148

17 Luo Y, Tang L, Khan U, et al. Morphology and surface chemistry engineering toward $\mathrm{pH}$-universal catalysts for hydrogen evolution at high current density. Nat Commun, 2019, 10: 269

$18 \mathrm{Yu} \mathrm{L}, \mathrm{Wu} \mathrm{L}, \mathrm{McElhenny} \mathrm{B}$, et al. Ultrafast room-temperature synthesis of porous S-doped $\mathrm{Ni} / \mathrm{Fe}$ (oxy)hydroxide electrodes for oxygen evolution catalysis in seawater splitting. Energy Environ Sci, 2020, 13: 34393446

19 Qian Q, Li Y, Liu Y, et al. Hierarchical multi-component nanosheet array electrode with abundant $\mathrm{NiCo} / \mathrm{MoNi}_{4}$ heterostructure interfaces enables superior bifunctionality towards hydrazine oxidation assisted energy-saving hydrogen generation. Chem Eng J, 2021, 414: 128818

20 Qian Q, Zhang J, Li J, et al. Artificial heterointerfaces achieve delicate reaction kinetics towards hydrogen evolution and hydrazine oxidation catalysis. Angew Chem Int Ed, 2021, 60: 5984-5993

21 Liu X, He J, Zhao S, et al. Self-powered $\mathrm{H}_{2}$ production with bifunctional hydrazine as sole consumable. Nat Commun, 2018, 9: 4365

22 Zhao M, Li H, Li W, et al. Ru-doping enhanced electrocatalysis of metal-organic framework nanosheets toward overall water splitting. Chem Eur J, 2020, 26: 17091-17096

23 Xie M, Ma Y, Lin D, et al. Bimetal-organic framework MIL-53(Co-Fe) An efficient and robust electrocatalyst for the oxygen evolution reaction. Nanoscale, 2020, 12: 67-71

24 Wu F, Guo X, Hao G, et al. Electrodeposition of sulfur-engineered amorphous nickel hydroxides on MIL-53(Fe) nanosheets to accelerate the oxygen evolution reaction. Nanoscale, 2019, 11: 14785-14792

25 Ren S, Duan X, Ge F, et al. Trimetal-based N-doped carbon nanotubes arrays on $\mathrm{Ni}$ foams as self-supported electrodes for hydrogen/oxygen evolution reactions and water splitting. J Power Sources, 2020, 480: 228866

26 Li FL, Shao Q, Huang X, et al. Nanoscale trimetallic metal-organic frameworks enable efficient oxygen evolution electrocatalysis. Angew Chem Int Ed, 2018, 57: 1888-1892

27 Salcedo-Abraira P, Vilela SMF, Babaryk AA, et al. Nickel phosphonate MOF as efficient water splitting photocatalyst. Nano Res, 2021, 14: 450457

28 Sun $\mathrm{H}$, Lian $\mathrm{Y}$, Yang $\mathrm{C}$, et al. A hierarchical nickel-carbon structure templated by metal-organic frameworks for efficient overall water splitting. Energy Environ Sci, 2018, 11: 2363-2371

29 Qiu B, Cai L, Wang Y, et al. Fabrication of nickel-cobalt bimetal phosphide nanocages for enhanced oxygen evolution catalysis. Adv Funct Mater, 2018, 28: 1706008

30 Chen $\mathrm{D}, \mathrm{Lu} \mathrm{R}, \mathrm{Pu} \mathrm{Z}$, et al. Ru-doped 3D flower-like bimetallic phosphide with a climbing effect on overall water splitting. Appl Catal BEnviron, 2020, 279: 119396

31 Zhang $\mathrm{H}$, Zhou W, Dong J, et al. Intramolecular electronic coupling in porous iron cobalt (oxy)phosphide nanoboxes enhances the electro- 
catalytic activity for oxygen evolution. Energy Environ Sci, 2019, 12: 3348-3355

32 Wang Z, Yang J, Wang W, et al. Hollow cobalt-nickel phosphide nanocages for efficient electrochemical overall water splitting. Sci China Mater, 2021, 64: 861-869

33 Zhang SL, Guan BY, Lou XWD. Co-Fe alloy/N-doped carbon hollow spheres derived from dual metal-organic frameworks for enhanced electrocatalytic oxygen reduction. Small, 2019, 15: 1805324

$34 \mathrm{Yu} \mathrm{X}$, Zhao J, Johnsson M. Interfacial engineering of nickel hydroxide on cobalt phosphide for alkaline water electrocatalysis. Adv Funct Mater, 2021, 31: 2101578

35 Lin Y, Wang H, Peng CK, et al. Co-induced electronic optimization of hierarchical NiFe LDH for oxygen evolution. Small, 2020, 16: 2002426

36 Sun F, Wang G, Ding Y, et al. NiFe-based metal-organic framework nanosheets directly supported on nickel foam acting as robust electrodes for electrochemical oxygen evolution reaction. Adv Energy Mater, 2018, 8: 1800584

Acknowledgements This work was supported by the National Natural Science Foundation of China (51772162 and 52072197), China Postdoctoral Science Foundation (2020M682135), the Postdoctoral Applied Research Project of Qingdao, the Outstanding Youth Foundation of Shandong Province, China (ZR2019JQ14), the Youth Innovation and Technology Foundation of Shandong Higher Education Institutions (2019KJC004), the Major Scientific and Technological Innovation Project (2019JZZY020405), the Major Basic Research Program of Natural Science Foundation of Shandong Province (ZR2020ZD09), and Taishan Scholar Young Talent Program (tsqn201909114).

Author contributions Liu X designed and engineered the samples; Yu Q and Chi J performed the experiments; Yu Q wrote the paper with support from Wang L; Chi J helped to modify the manuscript; all authors contributed to the general discussion.

Conflict of interest The authors declare that they have no conflict of interest.

Supplementary information Experimental details and supporting data are available in the online version of the paper.

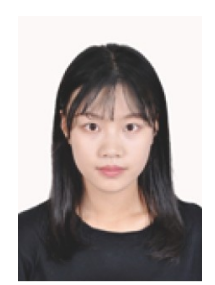

Qingping Yu is currently a master's candidate at Qingdao University of Science and Technology. She received her BSc degree from Qingdao University of Science and Technology (2020). Her research interests focus on the design and synthesis of MOF-derived materials for seawater splitting.

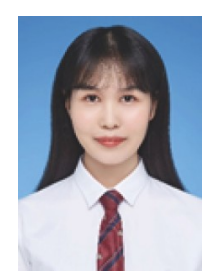

Jingqi Chi received a BSc degree from China University of Petroleum (East China). She received her MSc degree and $\mathrm{PhD}$ degree from the State Key Laboratory of Heavy Oil Processing, China University of Petroleum (East China). She is currently an associate professor at Qingdao University of Science and Technology. Her research interests focus on the design and synthesis of transition metal-based nanostructures and porous MOFs materials for electrochemical applications.

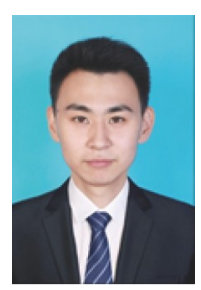

Xiaobin Liu is currently a postdoctor at Qingdao University of Science and Technology. He received his $\mathrm{PhD}$ degree from the Institute for Advanced Materials and Technology, University of Science and Technology Beijing. His research interests focus on the synthesis and application of MOF-derived materials.

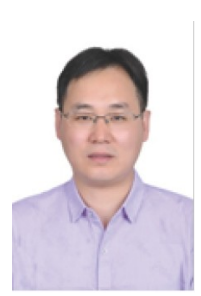

Lei Wang obtained his $\mathrm{PhD}$ degree in chemistry from Jilin University in 2006 under the supervision of Prof. Shouhua Feng. He moved to the State Key Laboratory of Crystal Materials, Shandong University, as a postdoctoral scholar from 2008 to 2010 . He is currently a professor of chemistry at Qingdao University of Science and Technology. His research interests mainly focus on the design and synthesis of functional organic-inorganic hybrids and porous MOFs materials, as well as their applications in photocatalysis, electrocatalysis, lithium-ion battery, etc.

\section{异质工程和阳离子掺杂双重策略促进肼辅助海水电 解节能制氢}

于青平 $1,2 \dagger$, 迟京起 $1,4 \dagger$, 刘桂杉 1,3 , 王宣艺 ${ }^{1,2}$, 刘晓斌 $1,3^{*}$, 李振江 ${ }^{1}$, 邓英 ${ }^{1,5}$, 王新萍 ${ }^{1}$, 王磊 $1,2,3^{*}$

摘要 与电解纯水制氢相比, 海水电解制氢具有更大的实际应用价值. 在碱性海水中, 可以通过在热力学上有利的肼氧化反应 $(\mathrm{HzOR})$ 代替析 氧反应 $(\mathrm{OER})$ 和析氯反应 $(\mathrm{ClER})$ 来实现节能制氢. 在此, 我们制备了 $\mathrm{Co}$ 掺杂的 $\mathrm{Fe}-\mathrm{Ni}_{2} \mathrm{P} / \mathrm{MIL}-\mathrm{FeCoNi}$ 异质结构阵列( $\mathrm{FeCo}-\mathrm{Ni}_{2} \mathrm{P} @ \mathrm{MIL}-\mathrm{FeCoNi}$ ). 得益于异质工程和阳离子掺杂的协同作用, $\mathrm{FeCo}-\mathrm{Ni}_{2} \mathrm{P} @ \mathrm{MIL}-\mathrm{FeCoNi}$ 在 碱性海水电解液中表现出优异的 $\mathrm{HzOR}$ 和析氢反应(HER)双功能电催 化性能. 在海水系统中的整体肼分解 $(\mathrm{OHzS})$ 仅需要 $400 \mathrm{mV}$ 的超低电压 就能达到 $1000 \mathrm{~mA} \mathrm{~cm}{ }^{-2}$ 的电流密度, 且可以在 $500 \mathrm{~mA} \mathrm{~cm}^{-2}$ 以上的电流 密度稳定运行 $1000 \mathrm{~h}$. 作为概念验证, 同样生产 $1.0 \mathrm{Nm}^{3}$ 的氢气, $\mathrm{OHzS}$ 海 水系统比无 $\mathrm{N}_{2} \mathrm{H}_{4}$ 的整体海水分解系统(OWS) 节省 $3.03 \mathrm{kWh}$ 的电力, 可 实现节能制氢. DFT计算表明, Co离子掺杂和构建FeCo-Ni $\mathrm{Ni}_{2} \mathrm{P} / \mathrm{MIL}-\mathrm{FeCoNi}$ 异质界面的协同作用可以降低FeCo- $\mathrm{Ni}_{2} \mathrm{P} @ \mathrm{MIL}-\mathrm{FeCoNi}$ 的水解离能垒, 促 进HER吸附氢和HzOR脱氢过程的热力学行为. 这项工作为有效利用海洋 能源领域中无限丰度的氢助力实现碳中和提供了一种实用途径. 